\title{
Extremely negative and inhomogeneous sulfur isotope signatures in Cretaceous Chilean Manto-type Cu-(Ag) deposits, Coastal Range of Central Chile
}

\author{
Javier Carrillo-Rosúa ${ }^{\mathrm{a}, \mathrm{b} *}$, Adrian J. Boyce ${ }^{\mathrm{c}}$, Salvador Morales-Ruano \\ b,d , Diego Morata e,f, Stephen Roberts ${ }^{\mathrm{g}}$, Francisco Munizaga ${ }^{\mathrm{e}}$, \\ Verónica Moreno-Rodríguez ${ }^{\mathrm{d}}$
}

${ }^{\text {a }}$ Departamento de Didáctica de las Ciencias Experimentales, Universidad de Granada, Facultad de Ciencias de la Educación, Campus de Cartuja, 18071, Granada, Spain (e-mail: fjcarril@ugr.es)

${ }^{\mathrm{b}}$ Instituto Andaluz de Ciencias de la Tierra (CSIC - Universidad de Granada), Avda. de las Palmeras 4, 18100 Armilla, Granada, Spain (e-mail: fjcarril@ugr.es; smorales@ugr.es)

${ }^{\mathrm{c}}$ Scottish Universities Environmental Research Centre (SUERC), East Kilbride, Glasgow G75 0QF, Scotland, United Kingdom (e-mail: a.boyce@suerc.gla.ac.uk)

${ }^{\text {d }}$ Departamento de Mineralogía y Petrología, Universidad de Granada, Facultad de Ciencias, Avd. Fuentenueva s/n 18002 Granada, Spain (e-mail: smorales@ugr.es; vmoreno@ugr.es)

e Departamento de Geología, Universidad de Chile, Plaza Ercilla 803, Santiago, Chile (e-mail: dmorata@cec.uchile.cl; fmunizag@cec.uchile.cl)

${ }^{f}$ Andean Geothermal Center of Excellence (CEGA-FONDAP), Universidad de Chile, Plaza Ercilla 803, Santiago, Chile (e-mail: dmorata@cec.uchile.cl)

${ }^{g}$ School of Ocean and Earth Science, National Oceanography Centre, University of Southampton, European way, So14 3ZH, United Kingdom (e-mail: sr1@noc.soton.ac.uk)

* Corresponding author: Tel.: +34 958243984; fax: +34 958243555 (e-mail: fjcarril@ugr.es)

\section{ABSTRACT:}

Chilean manto-type (CMT) $\mathrm{Cu}(-\mathrm{Ag})$ hydrothermal deposits share a characteristic association of volcanosedimentary Jurassic to Lower Cretaceous host rocks, style of mineralization, ore and associated mineralogy and geochemistry, with ore grades typically $>1 \% \mathrm{Cu}$, that make this family of deposits significant and interesting, both academically and economically. Although often stratabound, geological evidence supports an epigenetic origin for these deposits. We present a detailed stable isotope study of La Serena and Melipilla-Naltahua Lower Cretaceous deposits, central Chile, which reveals extremely negative $\delta^{34} \mathrm{~S}$ values, to $-50 \%$, which are among the lowest values found in any ore deposit. In addition, the range of $\delta^{34} \mathrm{~S}$ values from sulfides in the two areas is very wide: -38.3 to $-6.9 \%$ in La Serena, and -50.4 to $-0.6 \%$ in Melipilla-Naltahua. These new data significantly extended the reported range of $\delta^{34} \mathrm{~S}$ data for CMT deposits. Co-existing sulfates range from 7.9 to $14.3 \%$, and are exclusive to La Serena deposit. The wide sulfide isotopic range occurs at deposit and hand specimen scale, and suggests a polygenic sulfur source for these deposits, where bacteriogenic sulfide dominates. While sulfur isotope data for the bulk of Jurassic CMT deposits, northern Chile, suggests a predominant magmatic source in 
their origin (mean $=-2.7 \pm 1.9 \%, 1 \sigma$ ), contributions of a magmatic component is only likely to be involved at Melipilla-Naltahua deposit.

The $\delta^{13} \mathrm{C}$ values obtained for calcites associated with the mineralization range from -20.1 to $0.2 \%$ also suggesting polygenic carbon sources, with the likely strong involvement of degradation of organic matter and leaching of limestone.

Two different genetic models, with involvement of hydrocarbon, are proposed for both areas. For MelipillaNaltahua, a two-step model can be developed as follows: 1) Framboidal pyrite growth, with very low $\delta^{34} \mathrm{~S}$, formed by bacterial sulfate reduction in an open system, and with diagenetic degradation of oil-related brines, leaving pyrobitumen. 2) Cu-bearing stage, replacing of framboidal pyrite, inheriting depleted sulfur as low as $50.4 \%$, together with sulfides directly precipitated from a hydrothermal fluid with $\delta^{34} \mathrm{~S}$ close to $0 \%$. For La Serena, a single step model fits best, without framboidal pyrite generation. $\mathrm{Cu}$-bearing sulfides were precipitated mainly in veins where $\mathrm{Cu}$ plus base metal-bearing hydrothermal fluids mixed with $\mathrm{H}_{2} \mathrm{~S}$ generated by bacterial sulfate reduction in the host rocks. Isotopic evidence clearly illustrates that bacterial activity, perhaps enhanced by hydrothermal activity, was fed by hydrocarbon brines and sulfate remobilized from continental evaporites. It is possible that variable ecological conditions led to different extents of isotopic fractionation, adding to the typical sulfur isotopic heterogeneity of such bacterial systems. For both areas, the Cu-bearing stage occurred during the peak to waning stages of the very low-grade metamorphism that affected the Lower Cretaceous sequence.

\section{Keywords:}

Manto-type deposits; sulfur isotopes; bacterial sulfate reduction; copper; Coastal Range; Chile 


\section{Introduction}

Stratabound manto-type Cu-(Ag) deposits (Kojima et al., 2009; Maksaev and Zentilli, 2002; Sato, 1984; Sillitoe, 1989, Tristá Aguilera et al., 2006) are widely distributed in the Jurassic to Lower Cretaceous volcanosedimentary sequences of the Coastal Range of north and north-central Chile. These Chilean manto-type (CMT) deposits are relatively high grade, e.g. up to $200 \mathrm{Mt}$ with $1.34 \% \mathrm{Cu}$ at the El Soldado mine (Boric et al., 2002), with variable amounts of $\mathrm{Ag}$ as a by-product. Their origin is controversial (Maksaev and Zentilli, 2002), and while syngenetic models have been proposed (Ruiz and Peebles, 1988; Ruiz et al., 1965), local discordant structures have been observed, and geochronological data indicates that the orebodies were emplaced after the deposition of host rocks ( 1 Ma at the Michilla, Jurassic CMT deposit, Oliveros et al., 2008; $10 \mathrm{Ma}$ at El Soldado Cretaceous CMT deposit, Wilson et al., 2003a). Therefore, epigenetic models appear more realistic (Saric et al., 2003; Tassinari et al., 1993; Vivallo and Henriquez, 1998; Wilson et al., 2003b). Recently, it has been cogently argued that these deposits belong to the geotectonic spectrum of ores which includes the muchdebated Iron Oxide Copper Gold (IOCG; e.g. Barton and Johnson, 1996; Benavides et al., 2007; Sillitoe, 2003; Tornos et al., 2010), massive magnetite(-apatite) bodies, and small porphyry copper deposits (Maksaev and Zentilli, 2002), particularly related to the first main metallogenic event of the Andes: attenuated arc crust with high heat flow (Sillitoe, 2003). In addition, during the last decade, the discovery of an intimate association of pyrobitumen and copper mineralization has also been considered a key factor in the genesis of some of the Lower Cretaceous stratabound orebodies (Cisternas and Hermosilla, 2006; Cisternas et al., 1999; Haggan et al., 2003; Rieger et al., 2008; Wilson and Zentilli, 1999; Wilson and Zentilli, 2006; Wilson et al., 2003b; Zentilli et al., 1997). On balance, magmatism and metamorphism are seen as the main driving forces of CMT ore genesis (see Kojima et al., 2009, Maksaev and Zentilli, 2002, for recent reviews).

The following two models provide the current context for the interpretation of the key data from this paper, the sulfur isotope data. Two, very distinct sources of sulfur dominate current thinking on CMT deposits:

a) Sulfur of unspecified magmatic derivation: mainly argued for Jurassic deposits which have $\delta^{34} \mathrm{~S}$ between 7 and $0 \%$ (mean $=-2.7 \pm 1.9 \%$, 1б; Ramirez et al., 2006; Saric et al., 2003; Sasaki et al., 1984; Tristá-Aguilera, 2007; Vivallo and Henriquez, 1998). These values are not usual for magmatic systems given their homogeneity and proximity to the more usual $0 \pm 4 \%$ for primary magmatic rocks (Ohmoto, 1986). However, the strong temporal and spatial association of $\mathrm{Cu}$ with intense and very widespread volcanism resulting in several kilometers of flows and volcaniclastics, often hosting the ores, adds substance to the interpretation that volcanicderived sulfur is likely to be the main source.

Cisternas and Hermosilla (2006) also suggested a magmatic origin for some Lower Cretaceous CMT Cudeposits $325 \mathrm{~km}$ north of La Serena, even though they display very negative $\delta^{34} \mathrm{~S}$ values, to $-44.7 \%$. They suggested that the very low sulfur values were the result of an extreme redox process. However, such disproportionation would require an unreasonably low temperature to account for the extreme fractionation (Ohmoto and Lasaga, 1982), and it would also require that the system be dominated by sulfate (Rye, 1993), which, apart from La Serena, is very rare or absent in these deposits. Extreme acidity might also be expected in such a system (Rye, 1993), and this is not observed (e.g. lack of extreme carbonate dissolution, wholesale bleaching; development of vuggy silica; and absence of acid sulfate minerals). Moreover, sulfate, which occurs as barite in only a few Lower Cretaceous deposits such Cerro Negro with $\delta^{34} \mathrm{~S}_{\text {sulfate }} 9.6$ and $11.1 \%$, has also been argued to be of a magmatic source (Munizaga et al., 1994). We also disagree with this hypothesis since $\delta^{34} \mathrm{~S}_{\text {sulfide }}$ 
at this deposit is depleted to $-20 \%$, thus invoking an unreasonable isotopic disproportionation fractionation, and, again, acid alteration mineral assemblages are absent.

b) Sulfur produced by bacteriogenic sulfate reduction: originally postulated by Spiro and Puig (1988) and Munizaga et al. (1994) for some Lower Cretaceous deposits and evolved by Wilson et al. (2003b) for the Lower Cretaceous El Soldado deposit. The genetic model proposed for El Soldado deposit considers two mineralizing events (e.g. Boric et al., 2002; Wilson et al., 2003b): 1) an early (130 - $125 \mathrm{Ma})$ diagenetic low-temperature $\left(<100^{\circ} \mathrm{C}\right)$ stage, during which framboidal pyrite forms following migration of shale-derived petroleum in oilfield brines into suitable reservoirs, within the volcanic sequence. 2) A later (103 Ma) hydrothermal high temperature (up to $300-350^{\circ} \mathrm{C}$ ) event in which pyrite was replaced by Cu-bearing minerals with no significant isotopic homogenization, fractionation or addition of new sulfur. The resulting $\delta^{34} \mathrm{~S}_{\text {sulfide }}$, from -11.1 to $28.0 \%$ o (dominantly -6 to $+14 \%$ ), reflects incomplete sulfate reduction in a partially closed system of connate seawater sulfate during the first stage, although no isotopic analyses of primary sulfides (e.g. framboidal pyrite) were provided. This hydrothermal event occurred after peak very low-grade metamorphism and has been argued to be coincident with batholith intrusion (Wilson et al., 2003a), occurring in an extensional geological context (Vergara et al., 1995). Previous sulfur isotope studies on these Lower Cretaceous CMT deposits show a relatively large variation in $\delta^{34} \mathrm{~S}$, but the vast bulk of data falls between -8 and +3 (Munizaga et al., 1994; Puig and Spiro, 1988; Saric et al., 2003; Sasaki et al., 1984). With the exception of Wilson et al. (2003b) for the El Soldado deposit, few analyses are presented, and all, including El Soldado, use only conventional techniques.

Our study focuses on some Lower Cretaceous stratabound deposits in north-central and central Chile in which we have obtained extremely low $\delta^{34} \mathrm{~S}$ values. In particular: (i) the La Serena area, including the Talcuna mining district with around $15 \mathrm{Mt}$, at $1.5 \% \mathrm{Cu}$, (Boric, 1985) and (ii) the Melipilla-Naltahua area, including Melipilla and Naltahua districts. We present a significant sulfur dataset, including the first in situ laser sulfur isotopic analyses from this type of deposit, which is supplemented with carbon isotopes. These new data differ significantly from the previous studies, presenting a surprising, much greater range of data, especially to low $\delta^{34} \mathrm{~S}$ (among the lowest recorded in any ore deposit), which strongly confirms a significant role for bacteriogenic sulfide in the process of mineralization.

We propose a model for sulfide precipitation which integrates the observed $\delta^{34} \mathrm{~S}$ isotopic data and the mineralogical observations. While replacement and remobilization of a pre-existing bacteriogenic sulfide reservoir at the site of mineralization is plausible at Melipilla-Naltahua, that cannot be the case at La Serena. In the latter, bacteriogenic sulfur appears not to have been available at the deposition site, but was instead transported to the area.

\section{Geological setting}

The Lower Jurassic and Lower Cretaceous volcanic and volcano-sedimentary sequences along the Coastal Range in north and north-central Chile were respectively generated in extensional back-arc basins at an active convergent margin. They are the loci of intense volcanism and plutonism, and burial-induced very low-grade metamorphism (e.g. Aguirre, 1985; Aguirre et al., 1999; Oliveros et al., 2008).

The Lower Cretaceous forms an almost continuous, north-trending belt, $1200 \mathrm{~km}$ in length (from $25^{\circ} 30^{\prime}$ to $35^{\circ} 30^{\prime} \mathrm{S}$ ), up to $100-150 \mathrm{~km}$ wide, and 3-5 km thick. Thick, extensional volcanic plagioclase-rich porphyritic high-K calc-alkaline to shoshonitic basaltic andesites and andesite sequences dominate in central Chile (Aguirre, 
1985; Morata and Aguirre, 2003; Vergara et al., 1995). Shallow marine to continental sedimentary intercalations vary in abundance along the belt, but are volumetrically more important at northern latitudes. After volcanism, extension and basin subsidence, an anomalously high thermal gradient produced very low-grade metamorphism, coeval with plutonism (Aguirre et al., 1999; Levi et al., 1988; Morata et al., 2005).

In the La Serena region $\left(29^{\circ} 30^{\prime}\right.$ to $30^{\circ} 00^{\prime} \mathrm{S}$, Fig. 1), the Lower Cretaceous sequences are represented by the Hauterivian-Barremian Arqueros Formation comprising lava flows with shallow limestone intercalations (Aguirre and Egert, 1965), and the Quebrada Marquesa Formation, an Upper Barremian-Albian sequence of lava flows with continental volcaniclastic intercalations, and evaporites at the top of the sequence (Aguirre and Egert, 1965). The Quebrada Marquesa Formation hosts the stratabound copper deposits in the Talcuna mining district (Boric, 1985). A lava flow from the Arqueros Formation was dated at $114.1 \pm 0.5\left({ }^{40} \mathrm{Ar} /{ }^{39} \mathrm{Ar}\right.$ on primary Caplagioclase, Morata et al., 2008). A K-Ar age from celadonite associated with sulfides at the Talcuna mine of $93 \pm 2 \mathrm{Ma}$ is interpreted as the likely age of the main mineralization event (Morata et al., 2006).

In the Melipilla-Naltahua area $\left(\approx 33^{\circ} 50^{\prime} \mathrm{S}\right)$, the Lower Cretaceous sequence is represented by a bi-modal volcanic suite, with marine and continental sedimentary intercalations, the Lo Prado Formation (BerriasanHauterivian), and the basic volcanic-rich sequences of the Veta Negra Formation (Hauterivian-Barremian). The Melipilla mineralizations are hosted by andesites and by a carbonate sequence in the upper part of the Lo Prado Formation. Volcanism from the Veta Negra Formation has been dated by ${ }^{40} \mathrm{Ar} /{ }^{39} \mathrm{Ar}$ at around $120 \mathrm{Ma}$, whereas the mineralization is dated at $98 \pm 3 \mathrm{Ma}$ through a $\mathrm{K}-\mathrm{Ar}$ age on associated celadonite (Morata et al., 2006). The Naltahua district consists of small and dispersed former mines hosted by volcaniclastic sequences in the upper part of the Lo Prado Formation. These ores occur at a stratigraphic level that is correlated with that which hosts El Soldado (Boric et al., 2002) and other, smaller deposits.

Both areas are intruded by Lower to Upper Cretaceous granitoids (see Morata et al., 2008, Wall et al., 1999 and references therein), and were affected by very low-grade regional metamorphism, witnessed by the occurrence of albitization of plagioclase, and development of calcite, chlorite and the typical calc-silicates prehnite, pumpellyite and epidote (e.g. Carrillo-Rosúa et al., 2003; Morata et al., 2005).

Jurassic CMT deposits, which are restricted to northern latitudes $\left(22^{\circ}-26^{\circ} \mathrm{S}\right)$, are mostly hosted by volcanic rocks, which display rather similar geochemical characteristics to the volcanics hosting Lower Cretaceous CMT (Maksaev and Zentilli, 2002). However, Jurassic CMT deposits lack sedimentary rocks in their host sequence. The La Negra Formation hosts the ore deposits and is largely composed of high-K calc-alkaline to tholeiitic andesitic-basaltic rocks (e.g. García, 1967; Oliveros et al., 2007). Jurassic CMT deposits often occur near basic to intermediate sub-volcanic intrusive bodies but these intrusives are largely un-mineralized and some of them even postdate copper mineralization (e.g. Espinoza et al., 1996; Tristá-Aguilera et al., 2006). Available geochronological data suggest primary sulfide ores, although epigenetic, were emplaced shortly after deposition of the volcanic rocks and associated diorite intrusion (e.g. Oliveros et al., 2008; Tristá-Aguilera et al., 2006).

\section{Analytical methods}

Eighty-five ore and host rocks samples, thirty-five from La Serena and fifty from the Melipilla-Naltahua area, were analyzed petrographically by reflected and transmitted light microscopy and scanning electron microscopy. 
Sixty-eight samples from La Serena (24) and Melipilla-Naltahua (44) were then selected for isotopic analyses, with separates of sulfides, sulfates, calcite and pyrobitumen obtained by hand picking and microdrilling techniques. Six polished blocks from La Serena and five from Melipilla-Naltahua were also prepared for in situ laser combustion analyses. Five country rocks from Melipilla-Naltahua were processed by standard heavy mineral separation techniques to obtain sulfide separates. $\mathrm{SO}_{2}$ for conventional isotopic analyses was extracted by standard techniques from seventy-five sulfides and eleven sulfates following Robinson and Kusakabe (1975) and Coleman and Moore (1978) respectively. Fifty-seven in situ laser S isotope analyses were carried out, following Kelley and Fallick (1990) and Wagner et al. (2002). Liberated and purified gases were analyzed on a VG Isotech SIRA II mass spectrometer, and standard corrections applied to produce true $\delta^{34} \mathrm{~S}$. The standards employed were the international standards NBS-123 and IAEA-S-3, and SUERC standard CP-1. These give $\delta^{34} \mathrm{~S}$ values of $+17.1 \%$, $-31.5 \%$ and $-4.6 \%$ respectively, with $1 \sigma$ reproducibility around $\pm 0.2 \%$. Data are reported in $\delta^{34} \mathrm{~S}$ notation as per mil (\%) variations from the Vienna Canyon Diablo Troilite (V-CDT) standard.

$\mathrm{CO}_{2}$ for isotopic analyses was quantitatively released from forty-three calcites samples, 17 from La Serena and 26 from Melipilla-Naltahua, by the standard procedure of overnight reaction in vacuo with $100 \%$ phosphoric acid at $25^{\circ} \mathrm{C}$. Gases thus produced were analyzed on an AP 2003 mass spectrometer. Analytical raw data were corrected using standard procedures (Craig, 1957). Four pyrobitumen samples from Melipilla-Naltahua and La Serena were analyzed by continuous-flow isotope ratio mass spectrometry, involving a Carlo Erba C/N/S analyses interfaced with a Finningan Tracer Mat isotope ratio mass spectrometer. Isotope data are reported in standard $\delta$-notation as per mil (\%) deviations relative to the V-PDB (V-Pee Dee Belemnite) standard. Error of reproducibility, based on complete analysis of internal standards (including acid digestion for calcite and gelatine standard for pyrobitumen) was $\pm 0.2 \%$ ( $(\sigma)$.

Sulfur content of pyrobitumen was determined by a Cameca SX-50 electron microprobe (EPMA). Seventy analyses in three samples were obtained, $25 \mathrm{Kv}$ accelerating potential, $25 \mathrm{nA}$ bean current, $60 \mathrm{~s}$ acquisition time being the operating conditions. Three samples of separated pyrobitumen grains were also analyzed by an elemental analyzer (Fisions Carlo Erba EA 1108). Identification of minerals were confirmed by EPMA, and, in the specific case of $\mathrm{Cu}$-sulfides, XRD analyses (Phillips PW 1710, with $\mathrm{CuK} \alpha$ radiation) were used.

A microthermometric study of 26 (12 at La Serena, 14 at Melipilla-Naltahua) fluid inclusions was performed using a Linkam THMSG 600 heating-freezing stage. Obtained data using the cycling technique described by Goldstein and Reynolds (1994) are reproducible to $\pm 0.5^{\circ} \mathrm{C}$ and $\pm 5^{\circ} \mathrm{C}$ for freezing and heating runs, respectively.

\section{Mineralization}

The mineralization at Melipilla-Naltahua and La Serena is typically discontinuous, irregular or occurs as tabular orebodies, concentrated within porous host rocks, such as pyroclastic layers or at limestone-volcanic contacts. Vein style mineralization is also present, especially in La Serena. The Cu-(Ag) mineralization occurs as disseminations, replacement pockets, veins, crustiform bands, or filling vacuoles spatially associated with volcanic (La Serena area) and volcanic and carbonate rocks (Melipilla-Naltahua area). Barren porphyritic andesite dykes, which appear to be post-mineralization, are also commonly found in these localities, as they are in other CMT deposits (e.g. Susana-Lince, Kojima et al., 2003; El Soldado, Boric et al., 2002). Both areas share ore mineral characteristics (Fig. 2), with two distinct mineral associations: a) bornite-djurleite $\left(\mathrm{Cu}_{31} \mathrm{~S}_{16}\right)$ association, and b) $\mathrm{Cu}$-rich polymetallic association. 


\subsection{Bornite-djurleite association}

Bornite-djurleite intergrowths, often developing a symplectitic texture (Fig. 2a), appear filling vacuoles, disseminated in the volcanic rocks and at vein selvages, more abundantly at Melipilla-Naltahua than in La Serana. This association constitutes a minor proportion of the deposits. It is associated with minerals that appear in regional very low-grade metamorphism: prehnite, pumpellyite, zeolites, chlorite, albite, quartz, celadonite \pm calcite. Nevertheless, pumpellyite is absent in La Serena, but it is found in Melipilla-Naltahua intergrowtn with prehnite, chlorite and quartz (Fig. 2b). Thus, prehnite-pumpellyite facies metamorphism is evident at MelipillaNaltahua, while at La Serena, metamorphism only reach the zeolite facies. Some textures suggest a link between calc-silicate minerals, which precipitate early and Cu-bearing minerals that precipitated subsequently (Fig. 2b). Late euhedral djurleite and tenantite, closely associated with pyrobitumen, are also observed in pockets at La Serena.

\subsection{Polymetallic association}

The polymetallic association occurs as veins, sometimes crustiform-like, filling of vacuoles, and replacement in both volcanic and volcaniclastic rocks at La Serena and Melipilla-Naltahua, and also in sedimentary rocks at Melipilla-Naltahua. A greater mineralogical diversity in this association reveals significant differences between La Serena and Melipilla-Naltahua areas.

At La Serena, bornite and chalcopyrite are the major phases, with significant quantities of sphalerite, galena and tetrahedrite-tenantite (Fig. 2c), while arsenopyrite, stromeyerite, pyrite, carrolite, gersdorffite-cobaltite and an unidentified As-bearing phase are minor constituents. It is noteworthy that stromeyerite is the only Agbearing phase. Therefore, $\mathrm{Ag}$, is thought to be in $\mathrm{Cu}$-sulfides since $\mathrm{Cu}$-sulfides are demonstrated to bear $\mathrm{Ag}$ in minor amounts (Reich et al. 2010). Pyrite occasionally occurs as fine to coarse grains in the volcanic rocks, partially replaced by chalcopyrite, and as rare coarse grains in veins. The deduced paragenetic sequence is showed in figure 3 . The associated gangue minerals are barite (mainly before and during sulfide formation) and calcite (mainly during and after sulfide formation).

At Melipilla-Naltahua, chalcopyrite, bornite and pyrite (mainly framboidal) are the major phases (Fig. 2d) with minor tenantite, sphalerite, arsenopyrite, galena, marcasite and Ge-bearing sulfosalts. Here, barite is absent and calcite \pm celadonite \pm chalcedony are the most important gangue minerals. There is also an unusual association of coarse pyrite, chalcopyrite, magnetite (and also minor bornite and pyrrhotite) with quartz and chlorite found in veins in the volcanic rocks. This association resembles typical volcanic-hosted epithermal mineralization.

Small amounts of pyrobitumen (Fig. 2e) have been found in both areas usually cementing minerals of the bornite-djurleite association. In Melipilla-Naltahua spherical globules are common, whereas in La Serena pyrobitumen generally occurs in open spaces. Pyrobitumen has high carbon $(\sim 80 \pm 10 \mathrm{wt} . \%)$ with a sulfur content of $\sim 0.7 \mathrm{wt} . \%$ and $0.15-0.50 \mathrm{wt} . \%$, for La Serena and Melipilla-Naltahua respectively according to EPMA data. No sulfur content zonation (core-rim) was detected in the pyrobitumen grains.

The observed textural relationships indicate that the bornite-djurleite association at Melipilla-Naltahua is intersected by the polymetallic association, with pyrobitumen being deposited between both events (Fig. 3). At 
La Serena, bornite-djurleite and polymetallic association form a continuous sequence, with the former commonly appearing at the selvages of veins, with pyrobitumen occurring, at least, after the bornite-djurleite association (Fig. 3). At Melipilla-Naltahua, chalcopyrite and bornite replace (Fig. 2f) or overgrow framboidal pyrite (Fig. 2d). Polymetallic sulfides without a pyrite precursor are also a common feature at Melipilla-Naltahua. In La Serena there are textures suggesting replacement processes of pyrite, mainly in disseminated grains in the volcanic rocks. However fine laminations and overgrowth textures in veins are more common suggesting a direct precipitation of the sulfides from the hydrothermal fluids.

\subsection{Fluid inclusion data}

Petrographic observations show that fluid inclusions at La Serena and Melipilla-Naltahua are two-phase liquid plus vapor. Microthermometric determinations of a selection of fluid inclusions, shows temperatures of first melting (Te) lower than $-40{ }^{\circ} \mathrm{C}$ indicating that the fluids can be represented by the system $\mathrm{H}_{2} \mathrm{O}-\mathrm{NaCl}-\mathrm{CaCl}_{2}(-$ $\mathrm{KCl}$ ) (Shepherd et al., 1985). At La Serena, salinities range between 12.0 and $25.0 \mathrm{wt} . \% \mathrm{NaCl}$ eq. (average. 21.5 wt. $\% \mathrm{NaCl}$ eq.), while at Melipilla-Naltahua the values are slightly lowers (6.7 to $25.7 \mathrm{wt} . \% \mathrm{NaCl}$ eq, average: 10.4 wt.\% $\mathrm{NaCl}$ eq.). Temperatures of homogenization (Th) at La Serena ranges between 110 and $170^{\circ} \mathrm{C}$ (average: $140^{\circ} \mathrm{C}$ ), while at Melipilla-Naltahua are higher $\left(146\right.$ to $214^{\circ} \mathrm{C}$, average: $185^{\circ} \mathrm{C}$ ). True temperatures of entrapment could be appreciable higher $\left(10\right.$ to $\left.40^{\circ} \mathrm{C}\right)$ according to pressure corrections (Sheppard et al., 1985). It is noteworthy that differences among La Serena and Melipilla-Naltahua in hydrothermal minerals are also in accordance with differences in temperature of peak metamorphic.

In the La Serena area Oyarzun et al (1998) obtained Th in calcite (which are coeval to paragenetically later than sulfides), slightly lower (mainly between 90 and $160^{\circ} \mathrm{C}$ ). In contrast, Cucurella et al. (2003) recorded higher temperatures (between mainly 180 and $320^{\circ} \mathrm{C}$ ).

\section{Sulfur isotope results}

The $\delta^{34} \mathrm{~S}$ values obtained for sulfides in the two areas using conventional and laser analyses range from - 38.3 to $6.9 \%$ in the La Serena area, and from -50.4 to $-0.6 \%$ in the Melipilla-Naltahua area (Table 1, Fig. 4). This is an extraordinary range for CMT deposits, and contains some of the lowest ore sulfide $\delta^{34} \mathrm{~S}$ ever measured in any deposit. Considerable variation in $\delta^{34} \mathrm{~S}$ occurs within each deposit and, through the use of the in situ laser technique, is also demonstrated in individual samples. For example, a polymetallic vein from the La Serena area exhibits $\delta^{34} \mathrm{~S}$ values from $-38.3 \%$ in early galena, to $-27.9 \%$ in later tetrahedrite-tenantite (Fig. 2c). However opposite $\delta^{34} \mathrm{~S}$ trends are more common in other veins in La Serena: from $-15.3 \%$ in early bornite + chalcopyrite to $-29.3 \%$ in later chalcopyrite+sphalerite (Fig. 5). In the Melipilla-Naltahua area, sample MLP-123, with massive chalcopyrite cementing framboidal pyrite, exhibits chalcopyrite $\delta^{34} \mathrm{~S}$ around $-14.0 \%$ whereas framboidal pyrite and fine re-crystallized pyrite has $\delta^{34} \mathrm{~S}$ down to at least $-32.7 \%$ (Fig. 2d; due to fine-grain sizes, some cross-contamination was probable in these samples). Together with the bimodality of our data, this suggests that framboidal pyrite has a $\delta^{34} \mathrm{~S}$ lower than $-32.7 \%$, and cementing chalcopyrite may have $\delta^{34} \mathrm{~S}$ higher than $-14 \%$.

Despite the large range of $\delta^{34} \mathrm{~S}$ values exhibited by each mineral phase, and mineral associations, some systematic patterns are observed: a) framboidal pyrite is found only in Melipilla-Naltahua area, and sulfides with 
evidence of framboidal pyrite replacement always show a very low $\delta^{34} \mathrm{~S}$ signature, however $\mathrm{Cu}$-sulfides with very depleted sulfur do not always shows signs of a framboidal pyrite precursor (Fig. 2d and f); b) in contrast, fine- to coarse-grained pyrite at La Serena exhibits the heaviest sulfur in this area: -6.9 to $-12.1 \%$, and is observed to be replaced by isotopically lighter chalcopyrite $(\sim-20 \%)$; c) bornite and bornite-djurleite intergrowths, show a bimodal distribution at Melipilla-Naltahua (Fig. 4); d) the unusual polymetallic association of Melipilla-Naltahua with coarse pyrite+chalcopyrite+magnetite with quartz + chlorite gangue shows relatively high $\delta^{34} \mathrm{~S}$ values (between -6.0 and -2.6\%, Fig. 4).

The $\delta^{34} \mathrm{~S}$ of barite, which exclusively occurs in La Serena (Fig. 4), ranges between 7.9 and 14.3\%, although the majority of the results are rather isotopically homogeneous $(10.3 \pm 1.9 \%)$. The highest $\delta^{34} \mathrm{~S}(14.3 \%)$ is from a single sample of barite precipitated in the latest stages of the main sulfide deposition episode (Fig. 5).

Pyrite extracted from the nearest Cretaceous granitoid outcrop in the Melipilla-Naltahua area ( $85 \pm 10 \mathrm{Ma}$, KAr in amphibole, Wall et al., 1999) has $\delta^{34} \mathrm{~S}$ between 1.4 and 2.1\%o. Pyrites in sub-volcanic, unmineralized, but relatively pyrite-rich dikes, sampled in the Melipilla-Naltahua district have $\delta^{34} \mathrm{~S}$ between -5.3 and $-3.2 \%$. Pyrite extracted from black-limestone has $\delta^{34} \mathrm{~S}$ between 2.1 and $-0.2 \%$, whereas pyrite from black-shale has a $\delta^{34} \mathrm{~S}$ of 20.1\% (Table 1, Fig. 4). Finally, gypsum from evaporite rocks at the top of Quebrada Marquesa Formation at La Serena gives a $\delta^{34} \mathrm{~S}$ of $9.3 \%$ (Fig. 4).

\section{Carbon isotope results}

The $\delta^{13} \mathrm{C}$ values obtained for calcites range from -20.1 to $-3.1 \%$ in the La Serena area, and from -12.9 to $0.2 \%$ o in the Melipilla-Naltahua area (Table 1, Fig. 6). In La Serena, in calcites related to the polymetallic mineral association, the majority of the data are restricted in an interval between -10 and $-6 \%$. A depleted value, $-20.1 \%$, corresponds to the latest calcite in a vein where calcite shows a trend to lower $\delta^{13} \mathrm{C}$ values, associated with barite with the heaviest $\delta^{34} \mathrm{~S}$, and sulfides showing a depletion trend (Fig. 5). A single value for calcite of $-21 \%$, from a $\mathrm{Cu}$ deposit (Manto Delirio) in the La Serena is noted in Wilson and Zentilli (2006). In Melipilla-Naltahua, two types of calcite have been analyzed: one from the bornite-djurleite mineral association with relatively light carbon $\left(\delta^{13} \mathrm{C}\right.$ between -12.9 and $0.2 \%$, average of $-9.1 \%$ ) and another one from polymetallic mineral association with relatively heavy carbon $\left(\delta^{13} \mathrm{C}\right.$ between -6.9 and $0.1 \%$, average of $\left.-3.3 \%\right)$.

Pyrobitumen samples from Melipilla-Naltahua are characterized by $\delta^{13} \mathrm{C}$ between -27.1 and $-25.2 \%$, typical for marine-sourced hydrocarbon (-31 to $-25 \%$, Hunt, 1996). Cucurella et al. (2003) give a $\delta^{13} \mathrm{C}$ value of $-23.8 \%$ for a pyrobitumen sample from a $\mathrm{Cu}$ deposit from $\mathrm{La}$ Serena area. We also note that calcite samples associated with pyrobitumen show relatively low $\delta^{13} \mathrm{C}$ values (Table 1).

\section{Discussion}

\subsection{Relevance of the magnitude of measured $\delta^{34} S_{\text {sulfide }}$ range}

This work reveals one of the lowest $\delta^{34} \mathrm{~S}_{\text {sulfide }}$ values obtained to date (-50.4\%), not only for CMT Cu-(Ag) deposits, but also in any ore deposit (only exceeded by values down to $-70 \%$ found in supergene ores of a Carlin-type gold deposit, Bawden et al., 2003), although some Alpine, Irish-type and sediment-hosted Kupferschiefer $\mathrm{Cu}$ deposits approach similar negative values (Bechtel et al., 2001; Boyce et al., 1983; Gustafson 
and Williams, 1981; Schroll and Rantisch, 2005). The other striking feature of the data reported here, together with previous published data (Fig. 7), is the heterogenety of the new sulfide data, and the consequent extreme variations of $\delta^{34} \mathrm{~S}_{\text {sulfide }}$ values, ranging from -50 to $+28 \%$ for all $\mathrm{CMT} \mathrm{Cu}-(\mathrm{Ag})$ deposits. This range for sulfide sulfur is one of the broadest found in the nature, comparable to, for example, red bed $\mathrm{Cu}$ deposits (e.g. Gustafson and Williams, 1981; Ohmoto and Goldhaber, 1997). This work also reports the largest range of $\delta^{34} \mathrm{~S}_{\text {sulfide }}$ within a CMT deposit, $49.8 \%$ at Melipilla-Naltahua. At La Serena the range is also considerable: $45.2 \%$. Only Wilson et al. (2003b) noted similar $\delta^{34} \mathrm{~S}_{\text {sulfide }}$ range at El Soldado, although theirs was considerably shifted to more positive values (from -11.1 to $28.0 \%$ ).

Despite the apparent homogeneity of the age of this mineralizing event, the common nature of host rock, style of mineralization, mineralogy (mainly bornite, chalcopyrite and hypogene "chalcocite"- more likely djurleite as is demonstrated in the studied deposit here), moderate salinity of $<25 \%$ eq. $\mathrm{NaCl}$ and relatively low temperature fluid inclusions, below $250^{\circ} \mathrm{C}$ (data presented here; Boric et al., 2002; Maksaev and Zentilli, 2002; Oyarzun et al., 1998; Sillitoe, 1989; Vivallo and Henriquez, 1998), the distribution and range of the sulfide sulfur isotopic data indicate that there is unlikely to be a singular sulfur source for all CMT Cu-(Ag) deposits, and thus the details of the metallogenic model for each deposit may vary significantly.

\subsection{Dominant origin for sulfide sulfur at La Serena and Melipilla-Naltahua}

The range and highly negative sulfur values are characteristic of sulfide generated from bacteriogenic sulfate reduction. Bacteriogenic sulfate reduction is the source of the largest sulfur isotopic fractionations in nature, in some cases, up to $75 \%$ (Wortmann et al., 2001). While our measured range is greater than the $45 \%$ attained experimentally by bacteria single step reduction (e.g. Kaplan and Rittemberg, 1964), it is common in natural systems (e.g. Canfield and Teske, 1996; Wortmann et al., 2001). What is relatively uncommon, to date, about the CMT bacteriogenic systems is their geo-environmental setting, in that they are partially hosted by volcanic and/or volcaniclastic rocks in the thick volcanic sequences of the Coastal Range of Chile.

\subsection{Models for sulfide deposition}

We propose two different models for La Serena and Melipilla-Naltahua areas which could be also applicable to other CMT $\mathrm{Cu}-(\mathrm{Ag})$ deposits.

\subsubsection{Melipilla-Naltahua - a dual source with bacterial dominance}

We propose a two-step ore-formation for Melipilla-Naltahua (Fig. 3): 1) framboidal pyrite stage; 2) Cu-bearing sulfides. In situ laser analyses have shown that finely crystalline framboidal pyrite has $\delta^{34} \mathrm{~S}$ lower than around 30\% (Fig. 2d), which represents prima facie evidence of a low-temperature diagenetic stage. Our analyses also show that $\mathrm{Cu}$-sulfides (bornite and chalcopyrite), which host remnants of framboidal pyrite, are always characterized by very low $\delta^{34} \mathrm{~S}$ : bornite to $-50.4 \%$, with a mean of $-47.2 \pm 3.5 \%$. These values (approximately between -50 and $-30 \%$ ) most likely represent the most depleted end-member value for the bacteriogenic source, and maybe the main bacteriogenic sulfur signature. The framboidal pyrite formation could have occurred in the volcanic and sedimentary rocks during bacteriogenic degradation of migrating petroleum, with concomitant bacterial sulfate reduction, at low-temperature conditions: i.e. diagenesis, as has been suggested for El Soldado 
(Wilson et al., 2003b), and previous to very low-grade metamorphism that would volatized the oil. However, the bacteriogenic sulfate reduction at Melipilla-Naltahua has to have occurred in an open system with respect to sulfate, since the primary pyrites always exhibit very negative values, whereas a semi-closed system has been argued for El Soldado, where substantially more positive values are produced. Petroleum involvement is supported by the presence of bitumen that has $\delta^{13} \mathrm{C}<-25 \%$, suggesting a marine hydrocarbon source (Hunt, 1996), and the associated light carbon isotope signature of calcite in the earlier bornite-djurleite stage. The source of petroleum, would likely be the black limestones and black shales from the Lo Prado formation. Derivation of fluids from shales is also supported by Re-Os data in El Soldado deposit (Ruiz et al., 1997). The presence of variable amounts of pyrobitumen has been documented in many $\mathrm{Cu}$ deposits/districts in Lower Cretaceous sequences (Copiapó, La Serena, Uchimi, Cerro Negro, El Soldado, and Melipilla-Naltahua; Cisternas and Hermosilla, 2006; Cisternas et al., 1999; Zentilli et al., 1997; this work) and we would thus agree with previous authors that it has likely played a significant role in ore genesis.

The Cu-bearing ore-minerals formed during or shortly after very low-grade metamorphism that affected the Lower Cretaceous sequence, with the formation of bornite-djurleite mineral association first, and the $\mathrm{Cu}-\mathrm{rich}$ polymetallic association later. The bornite-djurleite association is intergrown with typical calc-silicates (prehnite, pumpellyite) and chlorite and often shows a symplectitic texture (Fig. 2a), and is thus consistent with growth during very low-grade metamorphism. This texture, a feature common in CMT deposits as a whole, suggests: i) decomposition of an earlier $\mathrm{Cu}$ sulfide to bornite-chalcocite, or ii) a replacement process with associated changes in the redox state (e.g. Sverjensky, 1987). Chalcocite transforms to djurleite when temperatures are less than $93^{\circ} \mathrm{C}$ according to its temperature stability (Potter, 1977). This process was possible due to relatively slow cooling rates, incompatible with typical dramatic hydrothermal temperature drops in shallow hydrothermal systems, but in accordance with a waning stage of a very low-grade metamorphic event. In fact, at El Soldado CMT deposit it is shown by fission track thermochronology in apatite that temperatures going down of $100^{\circ} \mathrm{C}$, more than $10 \mathrm{Ma}$ after metamorphic peak (Wilson et al., 2003a). The dominance of this texture in MelipillaNaltahua with respect to La Serena could be supported by the higher temperature regime deduced in the former, according to calc-silicate mineral assemblage (i.e. very low-grade metamorphic peak) and fluid inclusion data. In some areas (e.g. sample MLP-305-1) the hydrothermal Cu-bearing event involves replacement of diagenetic pyrite with no observed variation of $\delta^{34} \mathrm{~S}$ (Fig. 2f), and therefore could be expressed as: $\mathrm{Cu}^{+}+\mathrm{FeS}_{2}+0.5 \mathrm{H}_{2}$

$\mathrm{CuFeS}_{2}+\mathrm{H}^{+}$in the case of chalcopyrite formation (Eldridge et al., 1983). The acidity generated by this reaction could be easily neutralized by reaction with limestone, with concomitant space generation with enhance hydrothermal fluid circulation and ore deposition.

In other areas, the hydrothermal event not only introduced copper, but also isotopically heavy sulfur from another source (i.e. "hydrothermal source"). The polymetallic mineral association with coarse pyrite, chalcopyrite and magnetite, with $\delta^{34} \mathrm{~S}$ between -6.0 and $-2.6 \%$ show mineral and isotopic characteristic coherent with typical hydrothermal veins in volcanic rocks. This mineralization, plus some other sulfides also belonging to polymetallic (chalcopyrite) or bornite-djurleite mineral associations with $\delta^{34} \mathrm{~S}$ between -8 and $-1 \%$, correspond to the sulfides product of the other, end-member, sulfur source ("hydrothermal source") of MelipillaNaltahua mineralization.

It is difficult to establish the precise origin of this sulfur. We can rule out a simple magmatic source, since truly magmatic sulfides of the nearest granitoid yield a significantly higher, and typically magmatic $\delta^{34} \mathrm{~S}$ of 1 to 
2\%o (Fig. 4). A more likely possibility would be the dissolution of sulfides disseminated in the Lower Cretaceous volcano-sedimentary sequence and their subsequent homogenization by the hydrothermal fluid. Moreover, dykes in proximity to the mineralization are uncommonly sulfide-rich, with pyrite showing strikingly similar $\delta^{34} \mathrm{~S}(-5$ to $-3 \%$ ) to this polymetallic population ( -9 to $-1 \%$, Fig. 4), suggesting hydrothermal fluids may also channeled through these dykes. It is notable that this range of "hydrothermal" sulfur is similar to the signature that dominates in Jurassic CMT deposits, and is a signature that is also found in some previously studied Cretaceous CMT deposits (Lo Aguirre deposit in Saric et al., 2003).

We also suggest that the hydrothermal event probably resulted not only in oxidation of pyrobitumen, but also in substantial dissolution of limestone, given that the calcite of the polymetallic association shows relatively variable but isotopically heavy carbon (Fig. 6) as a result of this processes.

Finally, although a priori the full sulfur isotopic range in La Serena could be explained by a sole bacteriogenic origin, a two sulfur source (bacteriogenic and hydrothermal) is preferred by the conjunction of isotopic and geological observations. Early bornite-djurleite mineral association with a bimodal isotopic sulfur histogram, reflect most clearly these two sources, while polymetallic mineral association (in the case of galena, sphalerite and, in part, chalcopyrite) suggest a mixing of the sulfur of both sources.

\subsubsection{La Serena - contemporaneous bacterial source}

The El Soldado or Melipilla-Naltahua two-stage models for ore formation are not appropriate for La Serena deposits, since there is no evidence of early pyrite replacement, and very ${ }^{34} \mathrm{~S}$-depleted framboidal pyrite is absent: just the opposite, pyrite shows the heaviest sulfur signature of all sulfides (Fig. 4). Instead, features such as vein textures, including crustiform bands of sulfides, suggest the copper and sulfur directly precipitated sequentially from the hydrothermal fluids during mineralizing events.

Another significant characteristic of La Serena CMT deposit, which makes these deposits different to Melipilla-Naltahua or El Soldado, is the barite abundance, occurring mainly prior to contemporaneous sulfide precipitation. Such barite has a very homogeneous sulfur signature $(10.3 \pm 1.9 \%$, $1 \sigma$, Fig. 4), similar to other deposits in La Serena area: Mn stratabound $\left(\delta^{34} \mathrm{~S}\right.$ between 8 and 9\%, authors own data) and Ag-Ba vein deposits ( $\delta^{34} \mathrm{~S}$ between 9 and 10\%, Carrillo-Rosúa et al., 2006). This value is also similar to other Cretaceous CMT deposit such as Cerro Negro $\left(\delta^{34} \mathrm{~S}: 9.6-11.1 \%\right.$, Munizaga et al., 1994). These isotopic values rule out a derivation from seawater sulfate via remobilization of earlier evaporites, since the sulfur isotope signature of marine evaporites in the period 150 to $90 \mathrm{Ma}$ is 14 to $17 \%$ (Claypool et al., 1980). Nonetheless, evaporites are present within the volcano-sedimentary pile at the top of Quebrada-Marquesa Formation (Aguirre and Egert, 1965). A gypsum sample from this section at La Serena has a $\delta^{34} \mathrm{~S}$ of $9.3 \%$, which is coincident with the barite in the deposits. Such isotopic values are consistent with the evaporitic sulfate being formed in a continental, restricted basin environment (see, for example, the Ebro Basin sequence, Birnbaum and Coleman, 1979). We thus argue that remobilization of this continental evaporitic sulfate is the principal sulfur source for these deposits.

Calculated $\Delta_{\text {SO4-sulfide }}\left(=\delta^{34} \mathrm{~S}_{\text {sulfate }}-\delta^{34} \mathrm{~S}_{\text {sulfide }}\right)$ in the overall data (including pyrite, isotopically enriched and scarce), ranges between 15 and 54\%, but is typically significantly greater than 20\%o (Fig. 4 and 6). These values exclude thermochemical sulfate reduction as the main mechanism driving mineralization, as this process 
involves a typical isotopic kinetic fractionation of $\leq 15-20 \%$ (e.g. Machel et al., 1995; McGowan et al., 2003). Instead, bacterial sulfate reduction offers the most straightforward explanation of this extended fractionation.

The temperatures during the mineralization, according to the FI study, are higher than $120^{\circ} \mathrm{C}$ and therefore incompatible with bacterial activity (which needs less than about $120^{\circ} \mathrm{C}$, Kashefi and Lovley, 2003; Stetter et al., 1990). However, it is likely that bacterial communities developed in the surrounding volcano-sedimentary rocks at lower temperatures. Indeed, hydrothermal activity has been shown to enhance, rather than inhibit biological activity, including bacterial sulfate reduction (Weber and Jorgensen, 2002). Such hydrothermal activity can pyrolyze organic matter, and accelerate organic degradation, delivering an additional source of organic matter to the associated bacterial systems (Simoneit and Lonsdale, 1982)

A further carbon source for this biota could be derived from marine-derived hydrocarbons, as witnessed by the low $\delta^{13} \mathrm{C}$ of pyrobitumen found in La Serena (Fig. 6). $\delta^{13} \mathrm{C}$ of calcite, which is relatively homogeneous and depleted (Fig. 6), also supports this hypothesis, further suggesting that the isotopic signature could represent a mixture of organic carbon and bicarbonate derived from dissolution of marine limestone in the volcanosedimentary sequence.

Mineralogical observations in the La Serena deposits also suggest lower temperatures than in MelipillaNaltahua. Thus, the very low-grade metamorphic peak at La Serena corresponds to the zeolite facies conditions, contrasting with the prehnite-pumpellyite facies of Melipilla-Naltahua.

Overall, it appears likely that the key ore forming process was the mixing of $\mathrm{H}_{2} \mathrm{~S}$ generated by sulfate reducing bacteria in the host rocks of the Quebrada Marquesa Formation with hydrothermal $\mathrm{Cu}-(\mathrm{Ag}-, \mathrm{Pb}-, \mathrm{Zn}-)$ bearing fluids.

In detail, the observed sulfur isotopic heterogeneity on single specimen scale also points strongly to the activity of sulfate reduction bacteria. Thus, the isotopic trend to depleted sulfide sulfur observed in vein in Figure 5 , could be explained by the local changes in bacterial environment with time leading perhaps to a lower reduction rate and thus an increased fractionation (Kaplan and Rittenberg, 1964), although temperature variations and also organic substrate variations can also affect the extent of fractionation (Canfield, 2001). Whatever the cause, our data show examples of substantially increasing and decreasing fractionation of $\mathrm{S}$ isotope with time, typical of bacterial systems. We also note that if Figure $5, \delta^{34} \mathrm{~S}_{\text {sulfate }}$ increases up to $14 \%$, suggesting exhaustion of sulfate in a semi-closed system towards the end of the precipitation of this sample. Furthermore, this sample also shows very depleted carbonate sealing the vein $\left(\delta^{13} \mathrm{C}:-20.1 \%\right.$ ) recording an exhaustion of hydrothermal carbonate, and a dominance of organic-derived bicarbonate, perhaps associated with the reduction process.

\section{Final remarks}

Lower Cretaceous $\mathrm{CMT} \mathrm{Cu}-(\mathrm{Ag})$ deposit genesis is linked to an important metallogenic event, with the formation of numerous small to medium size deposits in a short interval of time due the conjunction of several factors in the Coastal Range of Chile:

a) Filling of different separate marine basins, with formation of organic-rich sediments probably in euxinic realms. These sediments constitute a petroleum source. Petroleum is subsequently implicated in the main sulfurforming stage, as key nutrient for sulfate reduction bacteria. This bacteriogenic sulfur is directly incorporated into ore minerals (the case of La Serena), or indirectly in a two-stage model with replacement process (the case 
of Melipilla-Naltahua). Jurassic CMT Cu-(Ag) deposits, and maybe some Lower Cretaceous deposits (e.g. Lo Aguirre, Saric et al., 2003) lacking this factor would be mostly dominated by magmatic/(metamorphic?) hydrothermal activity. The isotopic sulfur isotopic signature of these deposits is a rather homogeneous $\delta^{34} \mathrm{~S}$.

b) Extensional geodynamic context, combined with intense magmatic activity, with the formation of a thick (several km) stratigraphic pile suitable for copper (+ silver and other base-metals) leaching -as well as creating the genetically important continental evaporitic sulfate source.

c) Diagenesis to very low- to low-grade metamorphism coeval to intrusive activity provides geothermal gradient and extensional tectonic activity favorable for the development of hydrothermal activity.

The coincidence of these factors led to an important Lower Cretaceous metallogenic province with $\mathrm{Cu}-$ deposits characterized by sulfides not only with a huge $\delta^{34} \mathrm{~S}$ range, but also the lowest $\delta^{34} \mathrm{~S}$ values found in hypogene mineral deposits in nature. Local and regional differences are shown to clearly exist, and thus each deposit, while genetically related, should be considered within its own context when considering exploration and exploitation strategies.

\section{Acknowledgments}

This research has been supported by the Spanish project CGL2006-02594-BTE (Ministerio de Educación y Ciencia/Ministerio de Ciencia e Innovación and FEDER), the Chilean FONDECYT 1031000 project and the CSICUniversidad de Chile project CSIC/2001/02-08. Adrian J. Boyce is funded by NERC support of the Isotope Community Support Facility at SUERC. We thank Alison McDonald for her help during stable isotope analyses and Jason Newton for his assistance in carbon analyses of bitumen. We thank Mauricio Belmar (SGS, Chile), Tsuyoshi Nishimura, Roberto Belmar (Sociedad Minera Las Abuelitas Ltda.), Alonso Toledo (Palo Negro Mining Company) and Olga Veloso (Talcuna mining Company) for their collaboration on this research and for their help to access to the studied mines and samples. The manuscript was improved by suggestions and critiques of Profs. Marcos Zentilli and David Johnston.

\section{References}

Aguirre, L., 1985. The Southern Andes. In: Nairn, A.E.M. et al. (Eds.), The ocean basins and margins, vol. 7a. The Pacific Ocean . Plenum Press, New York, pp. 265-376.

Aguirre, L., Egert, E., 1965. Cuadrángulo Quebrada Marquesa. Provincia de Coquimbo. Carta Geológica de Chile. Instituto de Investigaciones Geológicas. Santiago, 15, 92 p.

Aguirre, L., Féraud, G., Morata, D., Vergara, M., Robinson, D., 1999. Time interval between volcanism and burial metamorphism and rate of basin subsidence in a Cretaceous Andean extensional setting. Tectonophysics 313, 433447.

Barton, M.D., Johnson, D.A., 1996. Evaporitic-source model for igneous-related Fe oxide-(REE-Cu-Au-U) mineralization. Geology 24, 259-262.

Bawden, T.M., Einaudi, M.T., Bostick, B.C., Meibom, A., Wooden, J., Norby, J.W., Orobona, M.J.T., Chamberlain, C.P., 2003. Extreme ${ }^{34} \mathrm{~S}$ depletions in $\mathrm{ZnS}$ at the Mike gold deposit, Carlin Trend, Nevada: Evidence for bacteriogenic supergene sphalerite. Geology 31, 913-916.

Bechtel, A., Sun, Y. Puttmann, W., Hoernes, S., Hoefs, J., 2001. Isotopic evidence for multi-stage base metal enrichment in the Kupferschiefer from the Sangerhausen Basin, Germany. Chem. Geol. 176, 31-49.

Benavides, J., Kyser, T.K., Clark, A., Oates, C., Zamora, R., Tarnovschi, R., Castillo, B., 2007. The Mantoverde Iron OxideCopper-Gold district, III región, Chile: The role of regionally derived, non magmatic fluids in chalcopyrite mineralization. Econ. Geol. 102, 415-440. 
Birnbaum, S.J., Coleman, M., 1979. Source of sulphur in the Ebro Basin (northern Spain) Tertiary non marine evaporite deposits as evidenced by sulphur isotopes. Chem. Geol. 25, 163-168.

Boric, R., 1985. Geología y yacimientos metálicos del Distrito Talcuna, Región de Coquimbo. Rev. Geol. Chile 25-26, 5775.

Boric, R., Holmgren, C., Wilson, N.S.F., Zentilli, M., 2002. The Geology of the El Soldado Manto type Cu (Ag) deposit, Central Chile. In: Porter, T.M. (Ed.), Hydrothermal Iron Oxide Copper-Gold \& Related Deposits. A Global Perspective. PGC Publishing, Adelaide, pp. 163-184.

Boyce, A.J., Coleman, M.L., Russell, M.J., 1983. Formation of fossil hydrothermal chimneys and mounds from Silvermines, Ireland. Nature 306, 545-550.

Canfield, D.E., Teske, A., 1996. Late Proterozoic rise in atmospheric oxygen concentration inferred from phylogenetic and sulphur-isotope studies. Nature 382, 127-132.

Canfield, D.E., 2001. Isotope fractionation by natural populations of sulfate-reducing bacteria. Geochim. Cosmochim. Acta $65,1117-1124$

Carrillo-Rosúa, F.J., Morales-Ruano, S., Morata Céspedes, D., Boyce, A.J., Belmar, M., Fallick, A.E., Fenoll Hach-Alí, P., Munizaga, F., 2006. Sulfur isotope studies in Chilean "Manto"-type Cu-(Ag) deposits in the Coastal Range of Central. In: V South American Symposium on Isotope Geology, Punta del Este, Uruguay.

Carrillo-Rosúa, F.J., Morales Ruano, S., Morata Céspedes, D., 2003. Mineral features of Cu-Ag-Ba-Mn mineralizations of La Serena, Chile. In: Eliopoulos, D.G. et al. (Eds.), Mineral exploration and sustainable development. Millpress, Rotterdam, pp. 953-956.

Cisternas, M.E., Frutos, J., Galindo, E., Spiro, B., 1999. Lavas con bitumen en el Cretácico Inferior de Copiapó: petroquímica importancia metalogénica. Rev. Geol. Chile 26, 205-226.

Cisternas, M.E., Hermosilla, J., 2006. The role of bitumen in strata-bound copper deposit formation in the Copiapó area, Northern Chile. Miner. Deposita 41, 339-355.

Claypool, G.E., Holser, W.T., Kaplan, I.R., Sakai, H., Zak, I., 1980. The age curves of sulfur and oxygen isotopes in marine sulfate and their mutual interpretation. Chem. Geol. 28, 199-260.

Coleman, M.L., Moore, M.P., 1978. Direct reduction of sulfate to sulphur dioxide for isotopic analysis. Anal. Chem. 50, 1594-1595.

Craig, H., 1957. Isotopic standards and isotopic correction factors for mass spectrometric analysis of carbon dioxide. Geochim. Cosmochim. Acta 12, 133-149.

Cucurella, J., Cisternas, M.E., Canut de Bon, C., Moreno, A., Schwark, L., 2003. Caracterización del bitumen presente en el yacimiento cuprífero, minas 21 de Mayo y nivel 2001 del distrito minero de Talcuna, Región de Coquimbo, Chile. In: Libro de Actas del X Congreso Geológico de Chile, Concepción, Chile.

Eldridge, C.S., Barton, P.B., Ohmoto, H., 1983. Mineral textures and their bearing on formation of the Kuroko ore bodies. Econ. Geol. Mn. 5, 241-281.

Espinoza, S., Véliz, H., Esquivel, J., Arias, J., Moraga, A., 1996. The Cupriferous Province of the Coastal Range, Northern Chile. In: Camus, F., Sillitoe, R.H., Petersen, R. (Ed.), Andean copper deposits: new discoveries, mineralization, styles and metallogeny. Soc. Econ. Geol., special publication n 5, pp. 19-32.

García, F., 1967. Geología del Norte Grande de Chile. In: Symposium sobre el Geosinclinal Andino, Sociedad Geológica de Chile, Santiago, 3, pp. 138.

Goldstein, R.H., Reynolds, T.J. 1994. Systematics of fluid inclusions in diagenetic minerals. Soc. Sedi. Geo., Short Course 31.

Gustafson, L.B., Williams, N., 1981. Sediment-hosted stratiform deposits of copper, lead, and zinc. In Skinner, B.J. (Ed.), Seventy-fifth Anniversary Vol. of Econ. Geol. 139-178.

Hagan, T., Parnell, J., Cisterna, M.E., 2003. Fluid history of andesite-hosted CuS-bitumen mineralization, Copiapó district, North Central Chile. J. Geochem. Explor. 78-79, 631-633. 
Hunt, J.M., 1996. Petroleum Geochemistry and Geology. $2^{\text {nd }}$ ed. W.H. Freeman and Company, New York.

Kaplan, I.R., Rittenberg, S.C., 1964. Microbiological fractionation of sulfur isotopes. J. Gen. Appl. Microbiol. 34, $195-212$.

Kashefi, K., Lovley, D.R., 2003. Extending the upper temperature limit for life. Science 301, 934.

Kelley, S.P., Fallick, A.E., 1990. High precision spatially resolved analysis of $\delta^{34} \mathrm{~S}$ in sulphides using a laser extraction technique. Geochim. Cosmochim. Acta 54, 883-888.

Kojima, S., Astudillo, J., Rojo, J., Tristá, D., Hayashi, K., 2003. Ore mineralogy, fluid inclusion, and stable isotopic characteristics of stratiform copper deposits in the Coastal Cordillera of northern Chile. Miner. Deposita 38, 208-216.

Kojima, S., Tristá-Aguilera, D., Hayashi, K., 2009. Genetic aspects of the manto-type copper deposits based on geochemical studies of north chilean deposits. Resour. Geol. 59, 87-98.

Levi, B., Nyström, J.O., Thiele, R., Åberg, G., 1988. Geochemical trends in Mesozoic-tertiary volcanic rocks from the Andes in central Chile and tectonic implications. J. S. Am. Earth Sci. 1, 63-74.

Machel, H.G., Krouse, H.R., Sassen, R., 1995. Products and distinguishing criteria of bacterial and thermochemical sulfate reduction. Appl. Geochem. 10, 373-389.

Maksaev, V., Zentilli, M., 2002. Chilean strata-bound Cu- (Ag) deposits: an overview. In: Porter, T.M. (Ed.), Hydrothermal Iron Oxide Copper-Gold \& Related Deposits. A Global Perspective. PGC Publishing, Adelaide, pp. 185-205.

McGowan, R.R., Roberts, S., Foster, R.P., Boyce, A.J., Coller, D., 2003. Origin of the copper-cobalt deposits of the Zambian Copperbelt: An epigenetic view from Nchanga. Geology 31, 497-500.

Morata, D., Aguirre, L., 2003. Extensional Lower Cretaceous volcanism in the Coastal Range $\left(29^{\circ} 20^{\prime}-30^{\circ} \mathrm{S}\right)$, Chile: geochemistry and petrogenesis. J. S. Am. Earth Sci. 16, 459-476.

Morata, D., Aguirre, L., Féraud, G., Belmar, M., 2005. Geodynamic implications of the regional very low-grade metamorphism in the Lower Cretaceous of the Coastal Range in central Chile. In: $6^{\text {th }}$ International symposium on Andean geodynamics, IRD editions, Barcelona, Spain, pp. 531-534.

Morata, D., Belmar, M., Pérez de Arce, C., Arancibia, G., Morales, S., Carrillo-Rosúa, F.J., 2006. Dating K-rich fine-grained phyllosilicates from mafic lithologies. An approach to constrain the timing of low-temperature processes in central Andes. In: V South American Symposium on Isotope Geology, Punta del Este, Uruguay.

Morata, D., Féraud, G., Aguirre, L., Arancibia, G., Belmar, M., Morales, S., Carrillo, J., 2008. Geochronology of the Lower Cretaceous volcanism from the Coastal Range at the $29^{\circ} 20^{\prime}-30^{\circ} \mathrm{S}$, Chile. Rev. Geol. Chile 35, 123-145.

Munizaga, F., Reyes, J.C., Nystrom, J.O., 1994. Razones isotópicas de S de los sulfuros del distrito minero de Cerro Negro: un posible indicador de los depósitos estratoligados de $\mathrm{Cu}$ hospedados en rocas sedimentarias lacustres. Rev. Geol. Chile 21, 189-195.

Munizaga, F., Zentilli, M., 1994. Caracterización isotópica del azufre de los depósitos estratoligados de Cu en Chile. Comunicaciones $45,127-134$.

Ohmoto, H., 1986. Stable isotope geochemistry of ore deposits. In: Ribbe, P.H. (Ed.), Stable isotopes in high temperature geological processes. Min. Soc. Am. pp. 491-599.

Ohmoto, H., Goldhaber, M.B., 1997. Sulfur and Carbon Isotopes. In: Barnes, H.L. (Ed.), Geochemistry of Hydrothermal Ore Deposit, 3rd edn. John Wiley \& Sons, New York, pp. 517-611.

Ohmoto, H., Lasaga, A.C., 1982. Kinetics of reactions between aqueous sulfates and sulfides in hydrothermal systems. Geochim. Cosmochim. Acta 46, 1727-1745.

Oliveros, V., Morata, D., Aguirre, L., Féraud, G., Fornari, M., 2007. Jurassic to Early Cretaceous subduction-related magmatism in the Coastal Cordillera of northern Chile $\left(18^{\circ} 30^{\prime}-24^{\circ} \mathrm{S}\right)$ : geochemistry and petrogenesis. Rev. Geol. Chile 34, 209-232.

Oliveros, V., Tristá-Aguilera, D., Féraud, G., Morata, D., Aguirre, L., Kojima, S., Ferraris, F., 2008. Time relationships between volcanism-plutonism-alteration-mineralization in $\mathrm{Cu}$-stratabound ore deposits from the Michilla mining district, northern Chile: $\mathrm{A}^{40} \mathrm{Ar} /{ }^{39} \mathrm{Ar}$ geochronological approach. Miner. Deposita 43, 61-78. 
Oyarzun, R., Ortega, L., Sierra, J., Lunar, R., Oyarzun, J., 1998. Cu, Mn and Ag minerlization in the Quebrada Marquesa Quadrangle: the Talcuna and Arqueros district. Miner. Deposita 33, 547-559.

Potter, R.W., 1977. An electrochemical investigation of the system copper-sulfur. Econ. Geol. 72, 1524-1542.

Robinson, B.W., Kusakabe, M., 1975. Quantitative preparation of SO2 for 34S/32S analyses from sulfides by combustion with cuprous oxide. Anal. Chem. 47, 1179-1181.

Ramirez, L.E., Palacios, C., Townley, B., Parada, M.A., Sial, A.N., Fernadez-Turies, J.L., Gimeno, D., Garcia-Valles, M., Lehman, B., 2006. The Mantos Blancos copper deposit: an upper Jurassic breccia-style hydrothermal system in the Coastal Range of Northern Chile. Miner. Deposita 41, 246-258.

Reich, M., Chryssoulis, S.L., Deditius, A., Palacios, C., Zúñiga, A., Weldt, M., Alvear, M. 2010."Invisible” silver and gold in supergene digenite (Cu1.8S). Geochim. Cosmochim. Acta 74, 6157-6173.

Rieger, A., Schwark, L. Cisternas, M.E., Miller, H., 2008. Genesis and evolution of bitumen in Lower Cretaceous lavas and implications for strata-bound copper deposits, North Chile. Econ. Geol. 103, 387-404.

Ruiz, C., Aguirre, L., Corvalán, J., Klohn, C., Klohn, E., Levi, B., 1965. Geología y yacimientos metalíferos de Chile. Instituto de Investigaciones Geológicas.

Ruiz, C., Peebles, F., 1988. Geología, distribución y génesis de los yacimientos metalíferos chilenos. Editorial Universitario, Santiago, Chile.

Ruiz, J., Freydier, C., McCandless, T., Chesley, J., Munizaga, F., 1997. Re-Os-isotope systematics of sulfides from basemetal porphyry and manto-type mineralization in Chile. Int. Geol. Rev. 39, 317-324.

Rye, R.O., 1993. The evolution of magmatic fluids in the epithermal environment: the stable isotope perspective. Econ. Geol. $88,733-753$

Saric, N., Kreft, C., Huete, C., 2003. Geología del yacimiento Lo Aguirre, Chile. Rev. Geol. Chile 30, 317-331.

Sasaki, A., Ulriksen, C., Sato, K., Ishihara, S., 1984. Sulphur isotope reconnaissance of porphyry copper and manto type deposits in Chile and the Philippines. Bull. Geol. Surv. Japan 35, 615-622.

Sato, K., 1984. Manto type copper deposits in Chile: a review. Bull. Geol. Surv. Japan 35, 565-582.

Schroll, E., Rantitsch, G., 2005. Sulphur isotope patterns from the Bleiberg deposit (Eastern Alps) and their implications for genetically affiliated lead-zinc deposits. Miner. Petrol. 84, 1-18.

SERNAGEOMIN 2002. Mapa Geológico de Chile. Servicio Nacional de Geología y Minería, Chile. Carta Geológica de Chile, Serie Geológica Básica No 75, 1 mapa en 3 hojas, escala 1:1.000.000. Santiago, Chile.

Shepherd, T., Rankin, A.H., Alderton, D.H.M. 1985. A practical guide to fluid inclusion studies. Blackie, Glasgow and London, $239 \mathrm{pp}$.

Sillitoe, R.H., 1989. Copper Deposits and Andean Evolution. In: Ericksen, G.E. et al. (Eds.), Geology of the Andes and its relation to hydrocarbon and mineral resources. Circum-Pacific Council for Energy and Mineral Resources, Earth Science Series, vol. 11, pp. 285-311.

Sillitoe, R.H., 2003. Iron oxide-copper-gold deposits: An andean view. Miner. Deposita 38, 787-812.

Simoneit, B.R.T., Lonsdale, P.F., 1982. Hydrothermal petroleum in mineralized mounds at the seabed of Guaymas Basin. Nature 295, 198-202.

Spiro, B., Puig, A., 1988. The source of sulphur in polymetallic deposits in the Cretaceous magmatic arc, Chilean Andes. J. S. Am. Earth Sci. 1, 261-266.

Stetter, K.O., Fiala, G., Huber, G., Huber, R., Srger, A., 1990. Hyperthermophilic microorganisms. Fems Microbiol. Rev. 75, 117-124.

Sverjensky, D.A., 1987. The role of migrating oil field brines in the formation of sediment-hosted cu-rich deposits. Econ. Geol. 82, 1130-1141.

Tassinari, C., Munizaga, F., Ramírez, R., 1993. Edad y geoquímica isotópica Rb-Sr del yacimiento de cobre Mantos Blancos: relación temporal con el magmatismo Jurásico. Rev. Geol. Chile 20, 193-206. 
Tornos, F., Velasco, F., Barra, F., Morata, D., 2010. The Tropezón Cu-Mo-(Au) deposit, northern Chile: The missing link between IOCG and porphyry copper systems? Miner. Deposita 45, 313-321.

Tristá-Aguilera, D., 2007. Génesis de los sulfuros de $\mathrm{Cu}$ primarios de los yacimientos estratoligados de $\mathrm{Cu}$ del Norte de Chile: el caso del Yacimiento Lince-Estefanía, Distrito Michilla, II Región de Antofagasta, Chile. Ph.D. Thesis Universidad Católica del Norte, Antofagasta, Chile.

Tristá-Aguilera, D., Barra, F., Ruiz, J., Morata, D., Talavera-Mendoza, O., Kojima, S., Ferraris, F., 2006. Re-Os isotope systematics for the Lince-Estefanía deposit: constraints on the timing and source of copper mineralization in a stratabound copper deposit, Coastal Cordillera of Northern Chile. Miner. Deposita 41, 99-105.

Vivallo, W., Henríquez, F., 1998. Génesis común de los yacimientos estratoligados y vetiformes de cobre del Jurásico Medio a Superior en la Cordillera de la Costa, Región de Antofagasta, Chile. Rev. Geol. Chile 25, 199-228.

Vergara, M., Levi, B., Nyström, J.O., Cancino, A., 1995. Jurassic and Early Cretaceous island arc volcanism, extension, and subsidence in the Coast Range of central Chile. Geol. Soc. Am. Bull. 107, 1427-1440.

Wall, R., Gana, P., Gutiérrez, A., 1999. Mapa geológico del área San Antonio-Melipilla, Regiones de Valparaiso, Metropolitana y del Libertador General Bernardo O'Higgins, escala 1:100.000. Servicio Nacional de Geología y Minería (Chile).

Wagner, T., Boyce, A.J., Fallick, A.E., 2002. Laser combustion analysis of $\delta^{34}$ S of sulfosalt minerals: determination of the fractionation systematic and some crystal-chemical considerations. Geochim. Cosmochim. Acta 66, 2855-2863.

Weber, A., Jorgensen, B.B., 2002. Bacterial sulfate reduction in hydrothermal sediments of the Guaymas Basin, Gulf of California, Mexico. Deep-Sea Res. Part I 49, 827-841.

Wilson, N.S.F., Zentilli, M., 1999. The role of organic matter in the genesis of the el Soldado volcanic-hosted Manto-type Cu deposit, Chile. Econ. Geol. 94, 1115-1136.

Wilson, N.S.F., Zentilli, M., 2006. Association of pyrobitumen with copper mineralization from the Uchimi and Talcuna districts, central Chile. Int. J. Coal. Geol. 65, 158-169.

Wilson, N.S.F., Zentilli, M., Reynolds, P. H., Boric, R., 2003a. Age of mineralization by basinal fluids at the El Soldado manto-type copper deposit, Chile: ${ }^{40} \mathrm{Ar} /{ }^{39} \mathrm{Ar}$ geochronology of K-feldspar. Chem. Geol. 197, 161-176.

Wilson, N.S.F., Zentilli, M., Spiro, B., 2003b. A sulfur, carbon, oxygen, and strontium isotope study of the volcanic-hosted El Soldado manto-type copper deposit, Chile: the essential role of bacteria and petroleum. Econ. Geol. 98, 163-174.

Wortmann, U.G., Böttcher, S.M., Bernasconi, S., 2001. Hypersulfidic deep biosphere indicates extreme sulfur isotope fractionation during single step microbial sulfate reduction. Geology 29, 647-650.

Zentilli, M., Munizaga, F., Graves, M.C., Boric, R., Wilson, N.S.F., Mukhopadhayay, P.K., Snowdon, L.T., 1997. Hydrocarbon involvement in the genesis of ore deposits: an example in Cretaceous strata-bound (manto-type) copper deposits of central Chile. Int. Geol. Rev. 39, 1-21. 
FIGURE 1

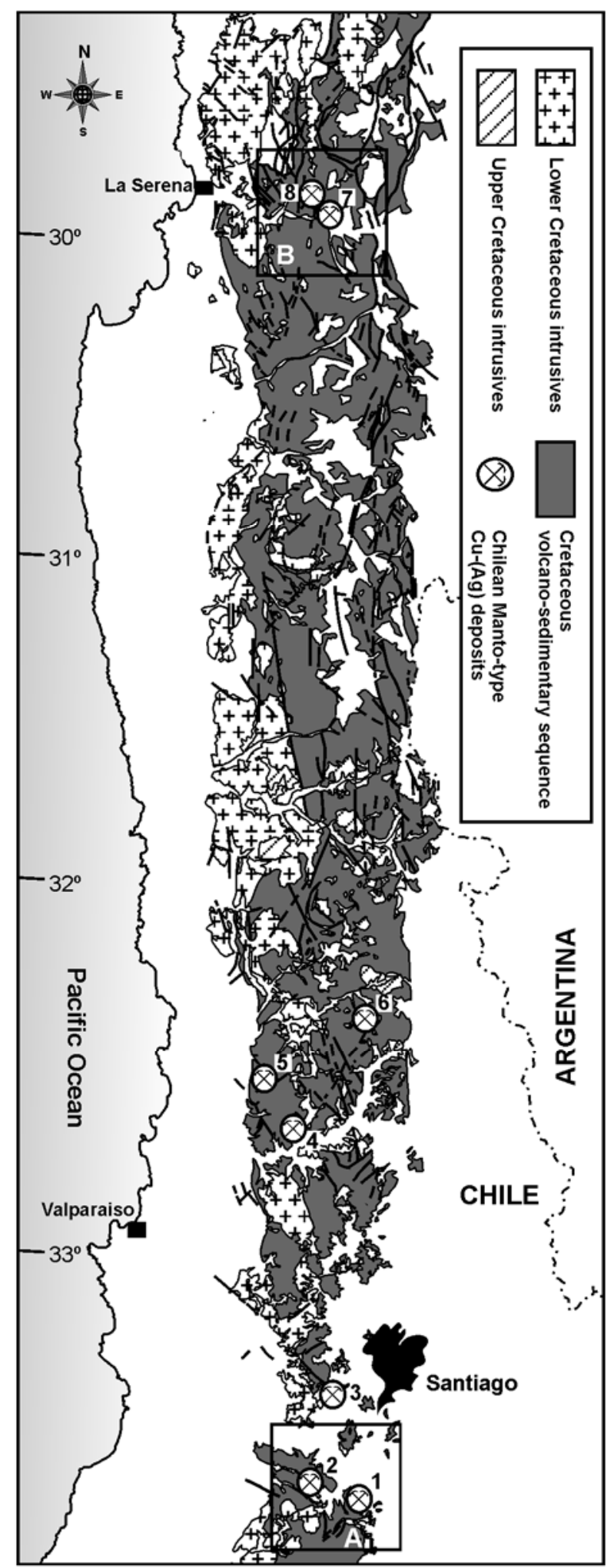

Figure 1. Simplified geological map of the Lower Cretaceous belt in the Coastal Range of north-central and central Chile (modified from SERNAGEOMIN, 2002) showing some of the main $\mathrm{Cu}$-mining district cited in the text. A: Melipilla area; B: La Serena area. 1: Naltahua district; 2: Melipilla district; 3: Lo Aguirre mine; 4: El Salado mine; 5: El Soldado mine; 6: Cerro Negro district; 7: Uchumi district; 8: Talcuna mine. 


\section{FIGURE 2}

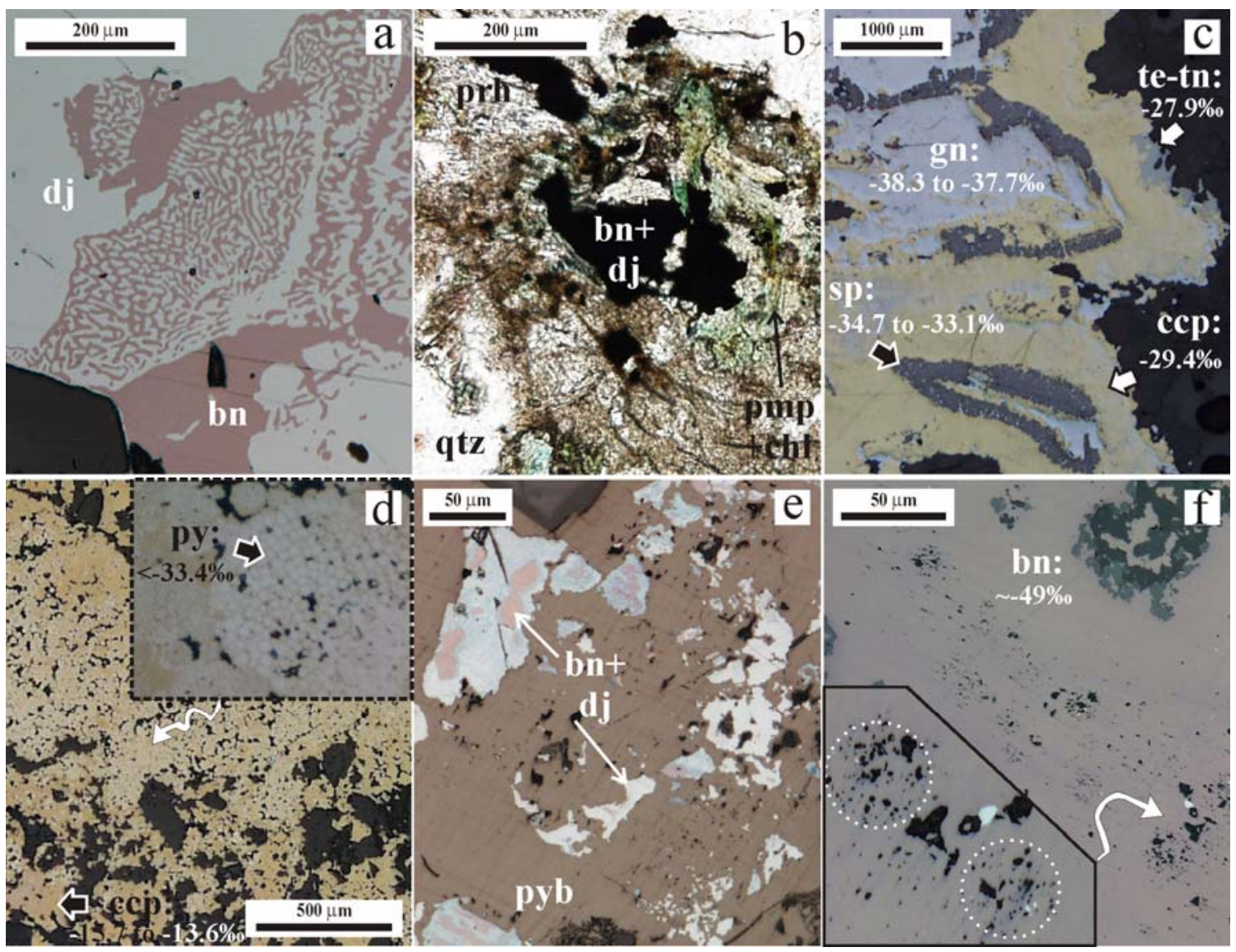

Figure 2. (a) Symplectitic intergrowth of bornite (bn) and djurleite (dj). (b) Bornite+djurleite associated with prehnite (prh), pumpellyite (pmp) and chlorite (chl) in a quartz (qtz)-rich pocket. (c) Polymetallic association with a succession of banded sulfides, ranging from galena (gn), sphalerite (sp), chalcopyrite (ccp) and, finally to tetrahedrite-tenantite (te-tn). (d) Massive chalcopyrite (ccp) cementing framboidal pyrite (py). (e) Pyrobitumen (pyb) bleb including crystals of bornite-djurleite association. (f) Bornite with a porous texture which suggests it was originated by the replacement of earlier pyrite framboids. The $\delta^{34} \mathrm{~S}$ values of sulfides obtained by in situ laser combustion analysis have been included in (c), (d) and (f) images. 
FIGURE 3

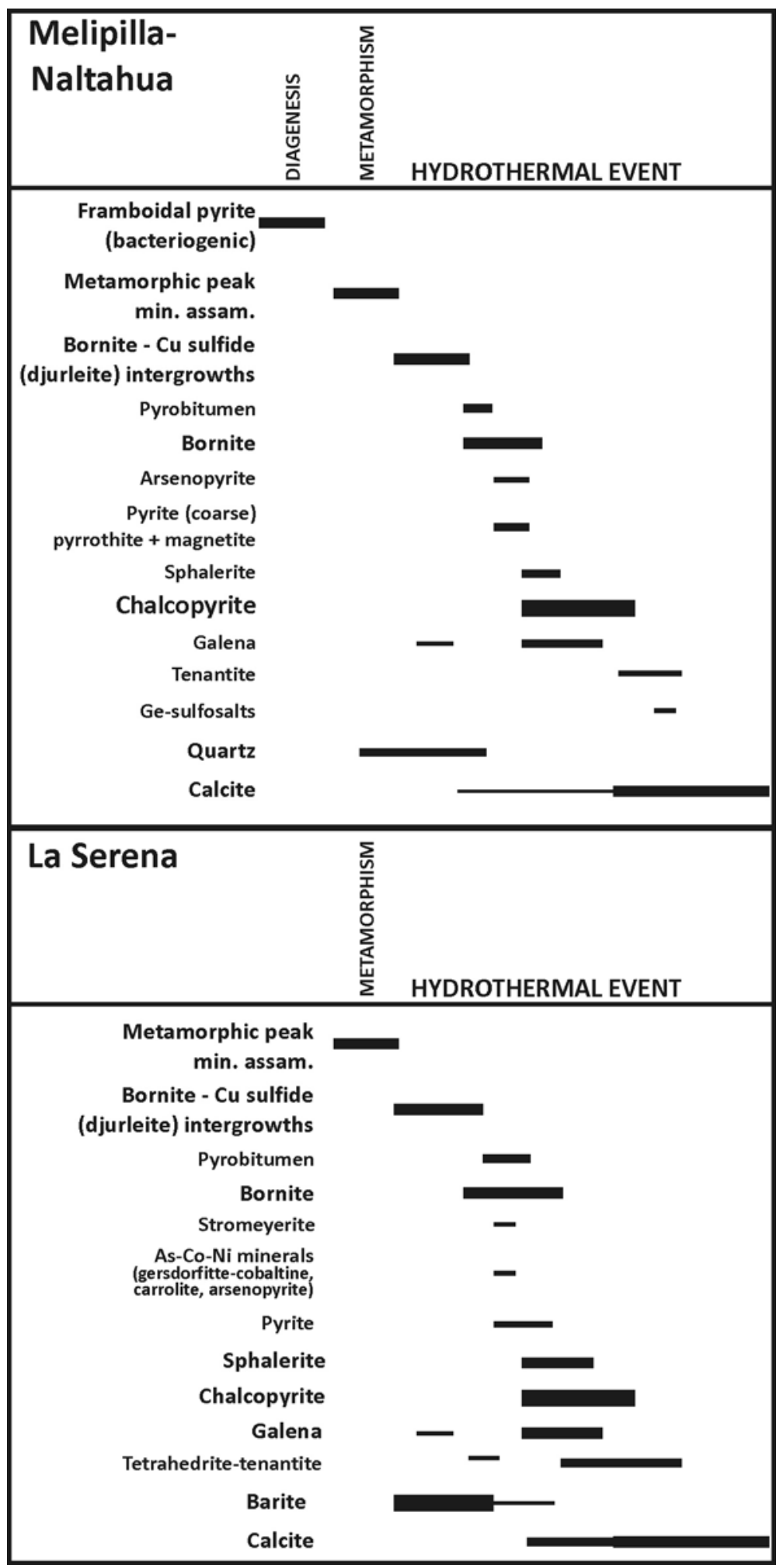

Figure 3. Paragenetic sequence of mineralizations at Melipilla-Naltahua and La Serena. The Hydrothermal Event is defined by the occurrence of copper mineralization. 
FIGURE 4

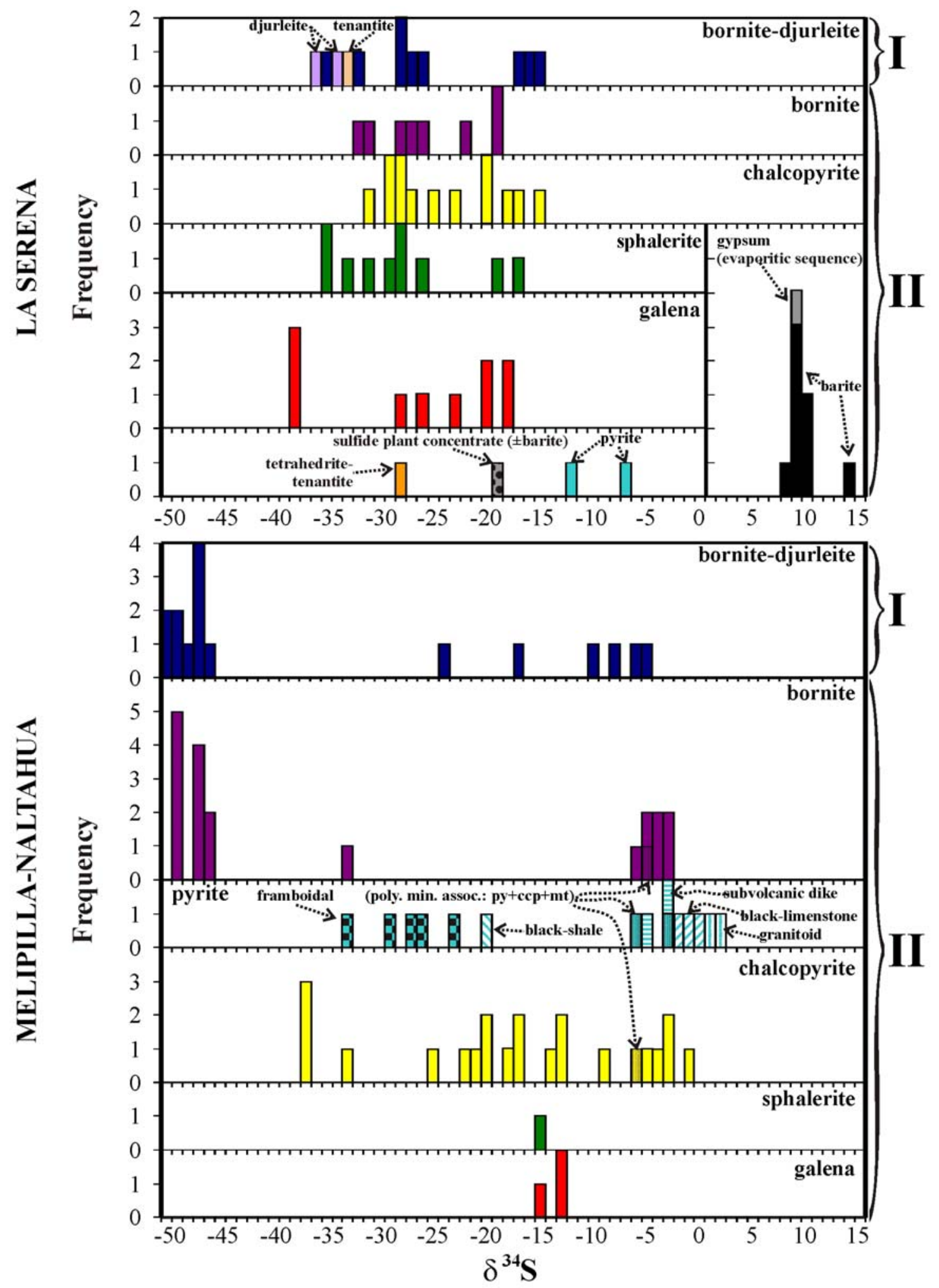

Figure 4. Histogram of $\delta^{34} \mathrm{~S}$ values obtained by conventional and laser-combustion techniques of sulfides and barite from different phases belonging to (I) bornite-djurleite and (II) $\mathrm{Cu}$-rich polymetallic mineral associations at the La Serena and Melipilla-Naltahua areas, as well as pyrite from different country rocks at Melipilla-Naltahua. 


\section{FIGURE 5}

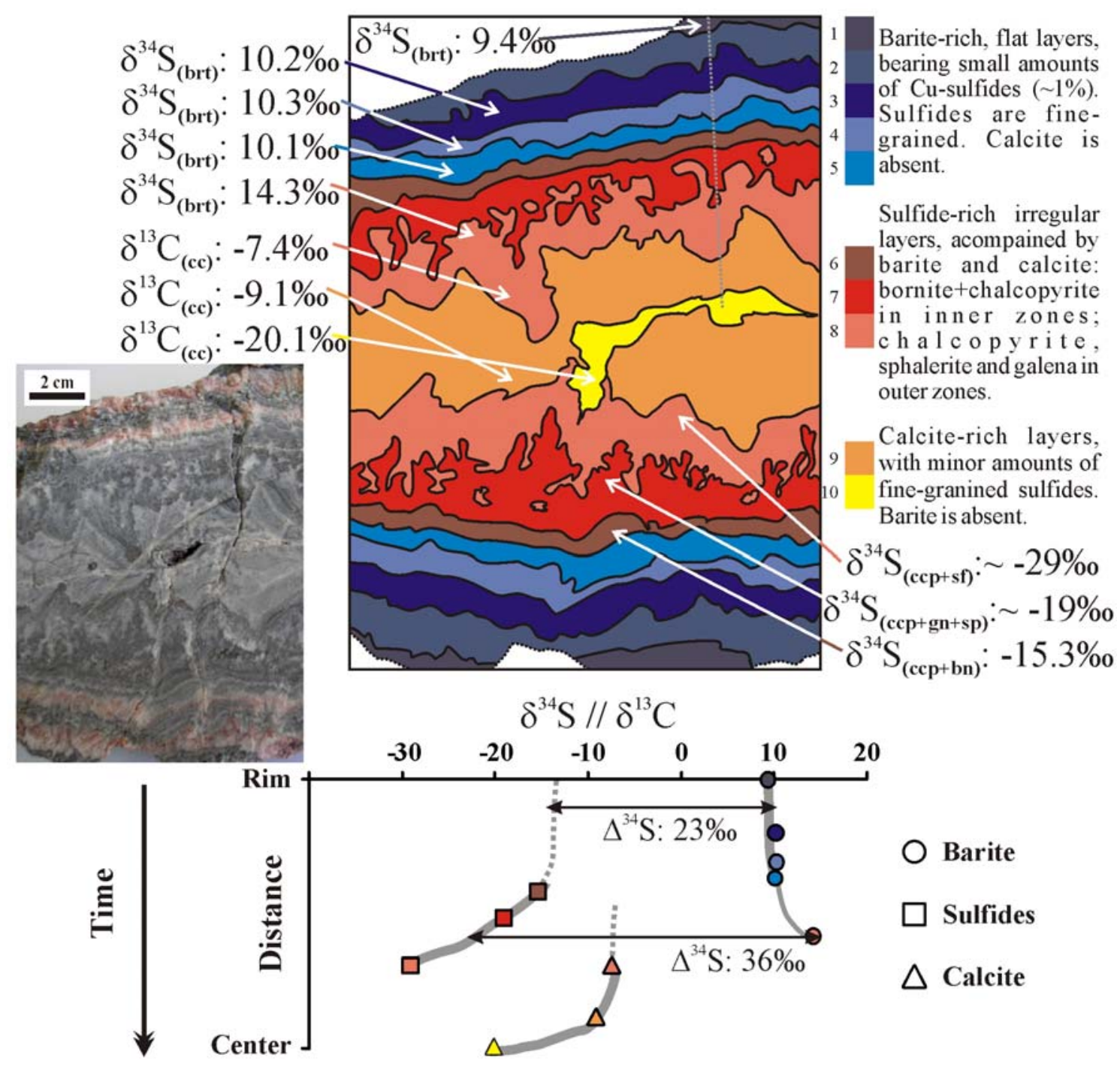

Figure 5. Diagram illustrating the layering sequence of a crustiform vein (photograph in the left side) from La Serena, with information about mineralogy and stable isotope geochemistry. Sulfides were analyzed by in situ laser combustion technique. Barite and calcite are extracted from the sample by microdrilling. 


\section{FIGURE 6}

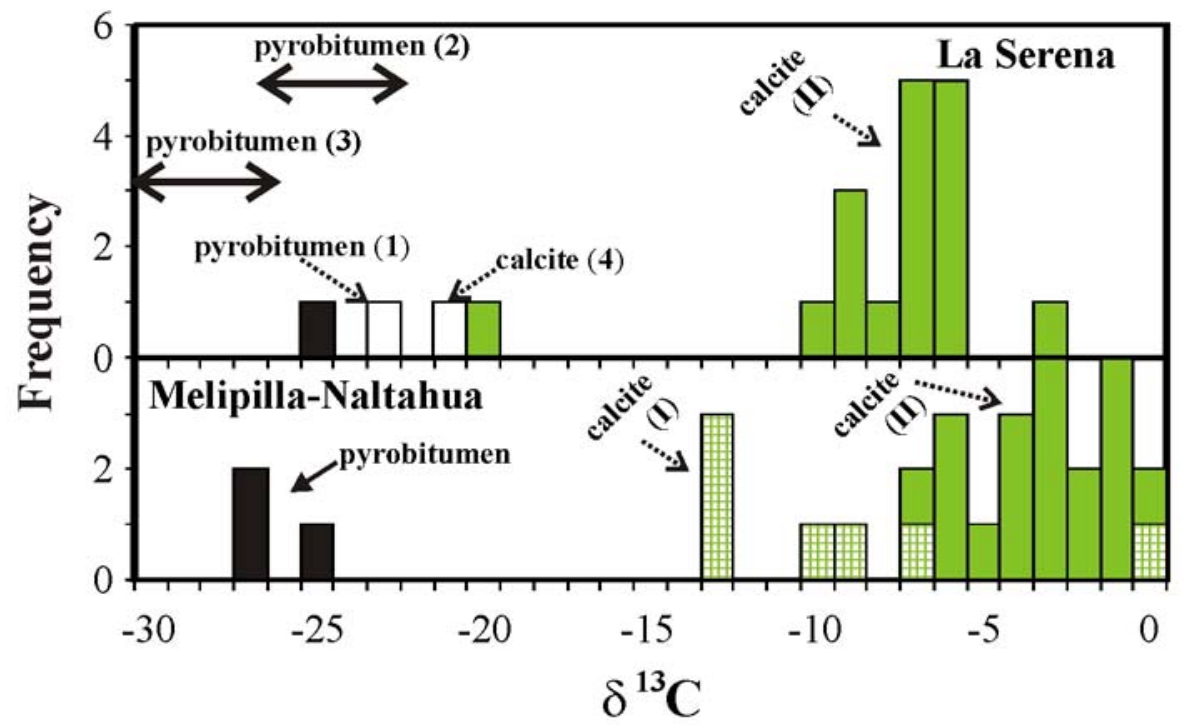

Figure 6. Histogram of $\delta^{13} \mathrm{C}$ values of calcites and pyrobitumen for (I) bornite-djurleite and (II) $\mathrm{Cu}$ rich polymetallic at the La Serena and Melipilla-Naltahua areas. Other values are also provided for comparison: (1) $\delta^{13} \mathrm{C}$ of pyrobitumen in La Serena area (Cucurella et al., 2003); (2) $\delta^{13} \mathrm{C}$ range of pyrobitumen from El Soldado deposit (Wilson et al., 2003b); (3) $\delta^{13} \mathrm{C}$ range of pyrobitumen from Copiapó deposit (Cisternas et al., 1999); and (4) $\delta^{13} \mathrm{C}$ of calcite from Manto Delirio from La Serena area (Wilson and Zentilli, 2006). 
FIGURE 7

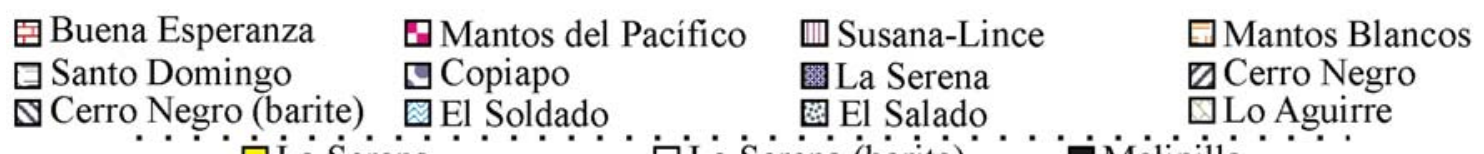

Mélipilla

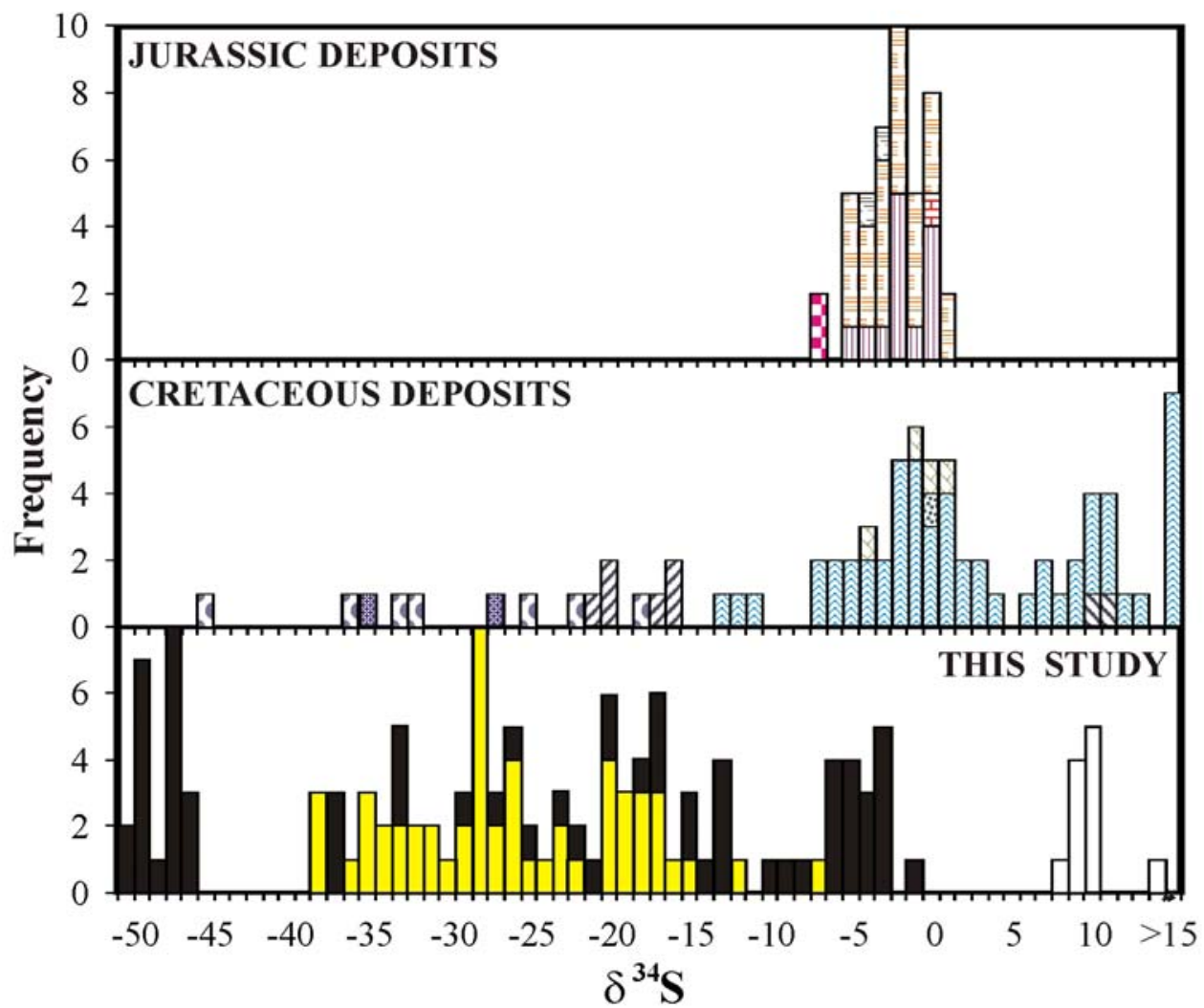

Figure 7. Histograms of $\delta^{34} \mathrm{~S}$ values obtained in this study in comparison with data published from CMT Cu-(Ag) deposits (data from Cisternas and Hermosilla, 2006; Munizaga and Zentilli, 1994; Munizaga et al., 1994; Ramirez et al., 2006; Saric et al., 2003; Sasaki et al., 1984; Spiro and Puig, 1988; Tristá-Aguilera, 2007; Vivallo and Henriquez, 1998; Wilson et al. 2003b). 
Table 1. Stable isotope analyses

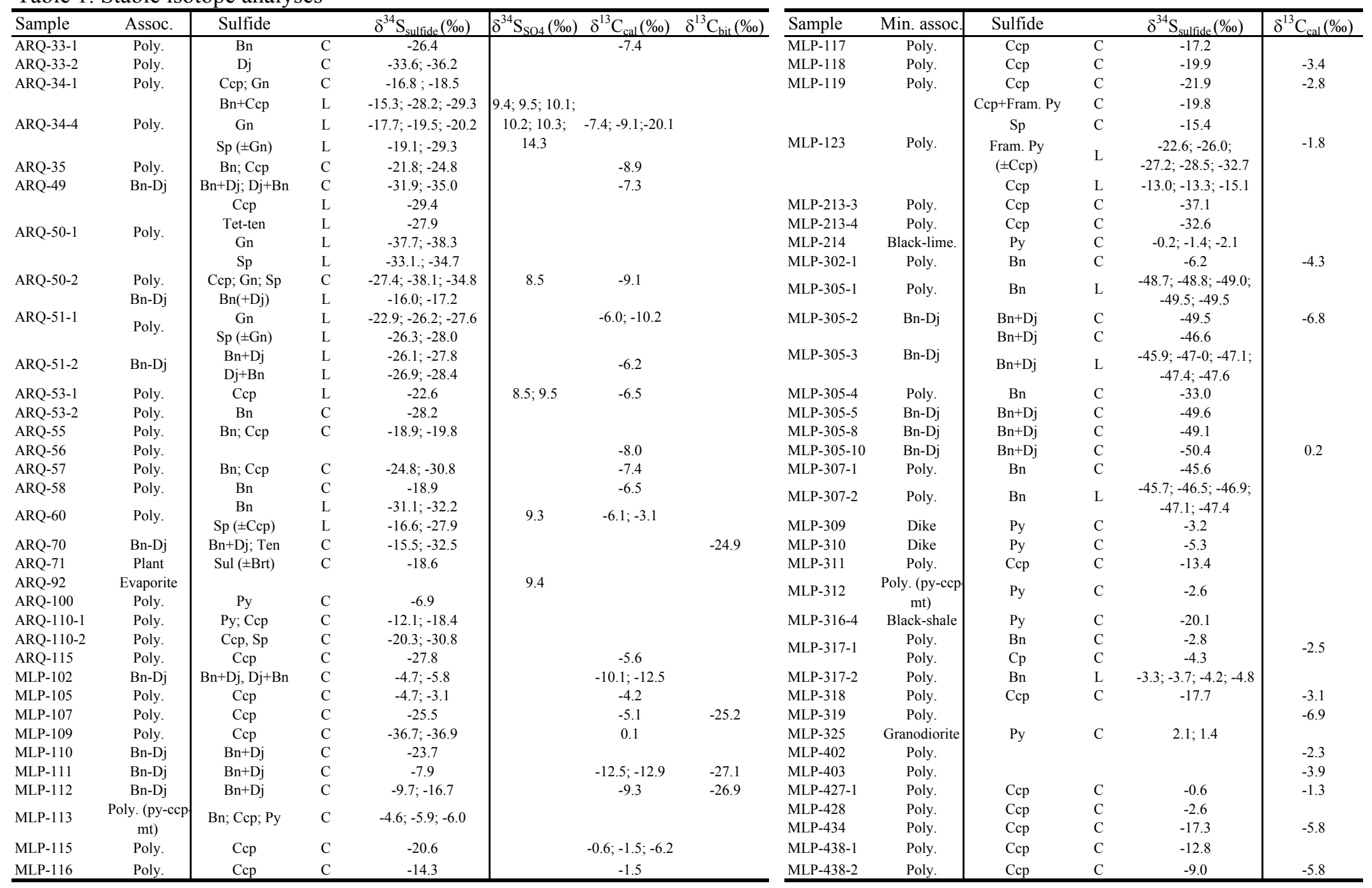

Note: Explanations and abbreviations: ARQ: samples from La Serena area; MLP: samples from Melipilla-Naltahua area; Assoc: association; Plant: a concentrate of sulfide with a small amount of barite from the processing plant; Poly: polymetallic association; $\mathrm{Bn}-\mathrm{Dj}$ : bornite-djurleite mineral association; $\mathrm{Bn}+\mathrm{Dj}$ : bornite + djurleite where bornite is more abundant than djurleite; $\mathrm{Dj}+\mathrm{Bn}$ : the opposite; $\mathrm{Brt}$ : barite; Ccp: chalcopyrite; Gn: galena; Py: pyrite; Fram. Py: framboidal pyrite; Sp: sphalerite; Ten: tenantite; Tet: tetrahedrite; Blac-lime: black limestone; C: conventional analyses; L: laser-combustion analyses. $\delta 34 \mathrm{SSO} 4$ correspond to analyses of barite, with exception of a gypsum analysis from evaporite in the country rocks (ARQ-92). 